\title{
New species of subterranean silverfish (Zygentoma: Nicoletiidae: Atelurinae) from Western Australia's semi-arid Pilbara region
}

\author{
Graeme B. Smith ${ }^{1,2^{*}}$ and Jane M. McRae ${ }^{3}$ \\ ${ }^{1}$ Australian Museum, 6 College St, Sydney, New South Wales 2010, Australia. \\ 2 Federation University Australia, PO Box 663, Ballarat, Victoria 3353, Australia. \\ ${ }^{3}$ Bennelongia Pty Ltd, 5 Bishop St, Jolimont, Western Australia 6014, Australia. \\ * Author for correspondence. Email: le_gbsmith@optusnet.com.au
}

\begin{abstract}
Three new species of the usually inquiline Atopatelurini, collected deep within ironore formations via mining bore holes, are described. Two species, Dodecastyla crypta sp. nov. and D. rima sp. nov. are placed in the Chilean genus Dodecastyla Paclt although certain ambiguities still exist regarding this genus. Troglotheus gen. nov. is erected for inclusion of T. bifurcus sp. nov. due to the absence of dorsal tergal chaetotaxy. Habitat data and possible host associations are discussed.
\end{abstract}

KEYWORDS: hypogean, troglophile, inquiline, iron-ore formations

\section{INTRODUCTION}

Silverfish of the family Nicoletiidae are well known from subterranean habitats. With the exception of the Atelurinae, the members of this family are elongate, primitively eyeless and generally lack pigmentation. While about half of all described non-atelurin species have been found in soil related habitats (in humus or under rocks), the remainder have been collected from within limestone caves (e.g. Mendes 1994) or from lava tubes (e.g. Espinasa and Espinasa Closas 2006, Smith 2006). Cave-adapted forms are often quite spindly with longer legs and sensory appendages. In recent years, biological survey work for mining companies in Western Australia has seen the sampling of fauna deep within various rock strata via drilled geological exploration holes. This has revealed a rich and highly adapted subterranean fauna (e.g. Guzik et al. 2010, Halse and Pearson 2014) consisting mostly of short range endemic species, restricted sometimes to a single outcrop. Smith et al. (2012) described silverfish species of the subfamily Subnicoletiinae sampled via such exploration holes in banded iron formations from the northern part of the Pilbara region in Western Australia.

The Atelurinae, once considered as an independent family (e.g. Watson 1970) but now treated as a subfamily within the Nicoletiidae, are considered as specialised for a living as inquilines or 'tolerated guests' of ants or termites. Many species, especially those hosted by termites, display striking morphological adaptations. These include a much more convex dorsum, a round or tear-drop shape and reduced appendage lengths, especially of the terminal filaments, and in extreme cases highly modified terminalia, particularly in the males. Other atelurin species seem to be quite flexible in their host associations and do not display the more extreme morphological adaptations. They can often be found in soil without any obvious host although they are usually not regarded as hypogean silverfish. On two occasions, however, one of us (Smith) has observed unidentified atelurins travelling with lines of ants deep within caves (Cape Range, WA and Undara, Qld) and on another occasion (also at Undara) high density populations (c. $30 / \mathrm{m}^{2}$ ) of Pseudogastrotheus sp. were sampled from the muddy floor of a lava tube without any obvious ant presence. This paper describes three new species of Atelurinae that have been collected from deep within rock formations via exploratory drill holes in the central part of the semi-arid Pilbara region of Western Australia.

The subfamily Atelurinae is quite diverse with some 70 described genera, many of which are monotypic. Mendes (2012) divides the subfamily into five tribes, placing all described Australian species within the Atopatelurini, a tribe characterised by the absence of scales on the head, the presence of a fovea but the lack of antennal apophyses on the pedicel of mature males, well developed molar regions of the mandibles, a galea with just one apical conule, legs with lyriform spines, the lack of specialised armature on the median dorsal appendage of mature males, pseudovesicles on urosternite VII and the presence of $1+1$ vesicles on urosternite VI which have a medial tuft of well developed setae. The tribe has a wide distribution with species described from Africa and the Middle East, South Asia, Indonesia, Papua-New 
Guinea, New Zealand, South America and Australia. Hosts include termites of the families Mastotermitidae, Termitidae and Rhinotermitidae as well as ants (Formicidae).

The Australian atelurin fauna is not well documented with only nine species having been described, despite many more being represented in various entomological collections. References to the genus Atelurodes Silvestri, 1916 in Australia (e.g. Smith 1998a), following the lead of Wygodzinsky (1963), are incorrect. Atelura similata Silvestri, 1908 with five pairs of abdominal stylets, requires redescription and will probably be placed within a new genus near Pseudogastrotheus Mendes, 2003 (with only four pairs of stylets).

This paper describes three new species from the Pilbara with six pairs of stylets, which along with other characters, appears to place them in or near the genus Dodecastyla Paclt, 1974 erected for the Chilean species Lepismina bifida Schäffer, 1897. Two of the three species will be placed, at least provisionally, in Dodecastyla Paclt. A new genus will be erected for the third species owing to its very different head and dorsal chaetotaxy. This position may need to be revised when more information becomes available on the chaetotaxy of the head and the presence of pulvilli in Dodecastyla bifida.

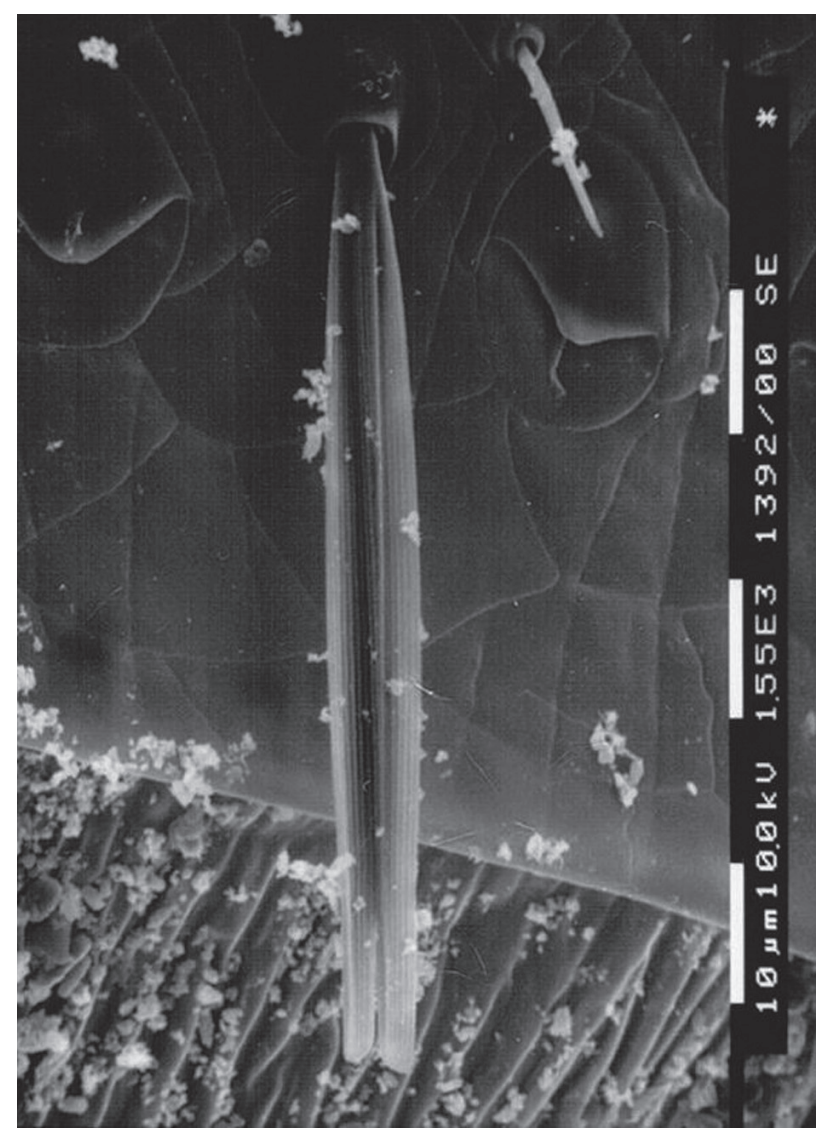

FIGURE 1 Australiatelura tasmanica (Silvestri, 1949): scanning electron micrograph of abiesiform macrochaeta with small setula to the upper right of it, above a typical scale insertion.

\section{MATERIALS AND METHODS}

\section{ABBREVIATIONS}

$\mathrm{I}-\mathrm{X}$

abdominal segments from anterior to posterior are numbered with roman numerals

HW head width (always in millimetres)

$\mathrm{H}+\mathrm{B}$

juv.

$\mathrm{L} / \mathrm{W}$

My

N, S, E, W

PI, PII, PIII

head and body length

juvenile

length to width ratio

million years

compass directions north, south, east, west (often in combination)

PVC prothoracic, mesothoracic and metathoracic legs respectively polyvinyl chloride (plastic)

\section{TERMINOLOGY}

Left and right are used in respect to the animal's left or right side when viewed from above with the head forward.

A new term will also be introduced in this paper for a type of tergal seta or macrochaeta common within the Atopatelurini. The shape of the individual macrochaetae can be quite significant for the Zygentoma and the term 'apically bifid' is used to describe a wide variety of forms, from quite delicate splits at the very apex, through the strong lyriform spines found on the legs of many atelurin species such as Atopatelura furcifera Silvestri, 1908 or Ausallatelura ordoarmata Smith, 2007 to the antennal macrochaetae of Crypturelloides mindeni Smith and Veera Singham, 2011, which are quite long yet bifurcated for up to $2 / 3$ of their length. Several genera, including Australiatelura Mendes, 1995 and Dodecastyla display flattened bifurcated setae along the posterior margins of the thoracic and abdominal tergites (Figure 1). In his redescription of Dodecastyla bifida (as Grassiella bifida) Silvestri (1905) describes these macrochaetae as short deeply apically incised scales 'Thorax et abdomen tergites squamis brevibus, latiusculis in apice sat profunde incisis' and for Australiatelura tasmanica (Silvestri, 1949) describes them as a transverse row of short, robust, apically incised setae 'serie transversali setarum robustarum brevium, in apice incisarum'. Mendes (1986) describes these as spathulate setae with a profound apical incision 'sedas espatuladas e com incisão apical profunda'. Stach (1935) commented that these setae resembled fir needles 'Diese Borsten errinern sehr an die Nadeln einer Tanne; die sind also zugeflacht, an der Spitze seicht gespalten und haben einer Mittelrippe'. The Latin word for fir is 'abies' which also forms the generic name for trees such as the Silver Fir (Abies alba Miller, 1768), which have needles that bear some resemblence to these flattened setae. Taking the lead from Stach, we would like to propose the use of the term 'abiesiform' to describe this distinct form of macrochaeta while recognising that there will be a degree of transition between the various types of macrochaetae. 


\section{STUDY AREA}

The Pilbara region in north-western Australian has been emergent for up to 3.5 billion years (Buick et al. 1995) and has experienced a range of climates. At the end of the Oligocene, the climate was temperate and the region supported small patches of rainforest. Aridity increased in the mid-Miocene (Macphail and Stone 2004, Martin 2006) and it is likely that some grounddwelling invertebrates began moving underground in the late Miocene or early Pliocene to escape the drying conditions. Although the major elements of the Pilbara's current climate came into place about 0.5 My ago, aridity has continued to increase (Martin 2006).

The Pilbara now has a semi-arid climate and mostly receives monsoonal rainfall as infrequent events during hot summers, although there is significant winter rain some years, especially in the southern Pilbara. Average annual rainfall is mostly $250-350 \mathrm{~mm}$ across the Pilbara and average temperatures in the hottest summer month (January) range from $36^{\circ} \mathrm{C}$ near the coast to $41^{\circ} \mathrm{C}$ inland (http://www.bom.gov.au/). Winters are warm and usually dry and annual pan evaporation is approximately 3500 $\mathrm{mm}$ (Luke et al. 2003).

The three species described here were collected from iron ore formations in two parts of the Hamersley Range in the central Pilbara (Packsaddle Range and Valley of the Queens) and from Cape Preston near the Pilbara coast (Figure 2). Vegetation in all three locations is dominated by spinifex grasses (Triodia spp.) with occasional eucalypt trees providing a very sparse overstorey. The areas sampled for troglofauna at Packsaddle Range were elevated ridgelines made up primarily of Brockman Iron Formation. Weathered sections of the iron formation at Packsaddle contain extensive fissures and voids to depths of up to $90 \mathrm{~m}$. Depth to groundwater was approximately $70-100 \mathrm{~m}$. At Valley of the Queens, sampling occurred on the valley floor or lower hill slopes, which mostly comprised Detrital Iron Deposit and alluvium/colluvium. The depth to groundwater was $8 \mathrm{~m}$ and there were abundant interstitial spaces in the iron deposit and alluvium above the water table. At Cape Preston, sampling occurred in Brockman Iron Formation. The depth to groundwater was $20-30 \mathrm{~m}$.

\section{COLLECTION METHODS}

Sampling occurred in holes drilled for geological exploration 1-2 years prior to sampling. The holes contained a short PVC collar extending from about $0.5 \mathrm{~m}$ above to $2 \mathrm{~m}$ below ground surface to prevent collapse of the drill hole. Holes were $150 \mathrm{~mm}$ in diameter and open (uncased) below the collar.

All type material was collected by scraping. This technique consisted of lowering a weighted conical net of made of 150 micron mesh to the bottom of the hole and scraping the net along the bore wall as it was retrieved, with the aim of dislodging troglofauna into the net (Halse and Pearson 2014). After retrieval and removal of as much rock and sediment as possible, the contents of the net were

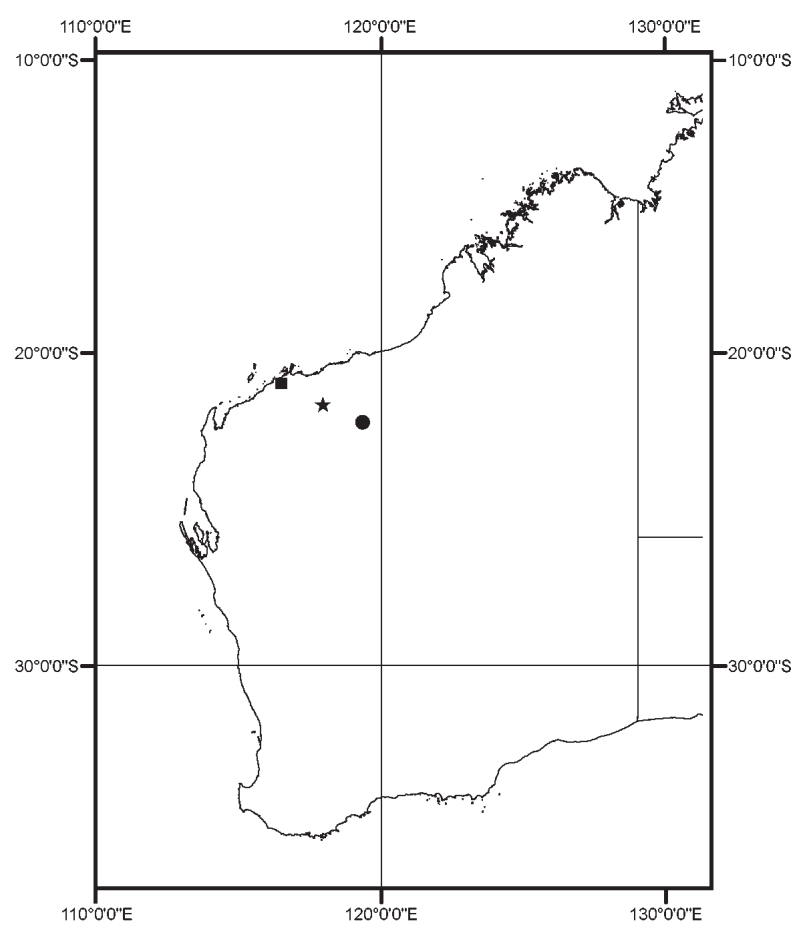

FIGURE 2 Localities of:

- Dodecastyla rima sp. nov.,

- Dodecastyla crypta sp. nov.

$\star$ Troglotheus bifurcus sp. nov.

preserved in $100 \%$ ethanol. Some additional animals were collected in PVC traps baited with leaf litter and set in the drill holes for eight weeks before retrieval.

\section{SPECIMEN PREPARATION}

After removal of a leg from the specimens which had been stored in $100 \%$ ethanol for possible DNA sequencing, the rest of the specimen was placed into $75 \%$ ethanol for a few months prior to the descriptive work in order to reduce fragility during handling or dissection. A series of measurements of most specimens was undertaken according to the method described in Smith (1998b). All silverfish specimens collected during this survey have been deposited with the Western Australian Museum, Perth. Unless specified as being mounted on slides, all specimens are stored individually in 80 or $100 \%$ ethanol. All specimens listed were examined, however the details required to separate the species are only seen with confidence on slide mounted material. Several male and one female specimen from each area were dissected and mounted onto two slides in Tendeiro solution with head and thorax on one slide and abdomen on the other (see Smith et al. 2012). No problems were encountered with twisting of the macrochaetae in the medium. Considering the fragility of subterranean silverfish, the specimens received were in reasonable condition although most terminal filaments were damaged to some degree, many setae had been lost and several specimens were broken into two pieces. One specimen (WAM E84137), which was already somewhat 
damaged on receipt, proved extremely difficult to dissect with sclerites tearing very easily and the tissue not separating from the cuticle. It is assumed that this was a freshly moulted specimen, where the cuticle had not fully hardened at the time it was captured and where the cuticle was still strongly attached to the underlying tissue. However all small subterranean nicoletiids seem to be quite delicate and easily damaged during dissection. Another problem was that a layer of very fine red dust adhered to the cuticle of some specimens, which made interpretation of the various structures more difficult.

\section{SYSTEMATICS}

\section{Family Nicoletiidae Escherich, 1905}

Nicoletiinae Escherich, 1905: 117.

\section{Subfamily Ateluriinae Remington, 1954}

Atelurinae Remington, 1954: 284.

\section{Tribe Atopatelurini Mendes, 2012}

Atopatelurini Mendes, 2012: 22.

\section{Genus Dodecastyla Paclt, 1974}

Lepismina Gervais: sensu Grassi and Rovelli, 1889: 3 (pro parte).

Grassiella Silvestri, 1898: 35 (pro parte).

Atelura von Heyden: Escherich, 1905: 118 (pro parte).

Dodecastyla Paclt, 1974: 545.

\section{TYPE SPECIES}

Lepismina bifida Schäffer, 1897, by original designation.

\section{Dodecastyla crypta sp. nov.}

Figures 3-46

http://www.zoobank.org/urn:Isid:zoobank. org:act:59E5657C-0A9B-4ABE-BBE7-936B8DA30EEF

\section{MATERIAL EXAMINED}

\section{Holotype}

Australia: Western Australia: (HW 0.63), Mining Area C, c. $92 \mathrm{~km} \mathrm{NW}$. of Newman, drill hole PSD0149R (2254'03.60"S, 118 59’34.70"E), 27 June 2010, collected by scraping root mat at about $10 \mathrm{~m}$ depth in drill hole which was $90 \mathrm{~m}$ deep in total, M.K. Curran, G.B. Pearson (WAM E84156) on two slides.

\section{Paratypes}

Australia: Western Australia: 1 (HW 0.70), same data as holotype (WAM E84157) in alcohol; 1 (HW 0.69), same data as holotype (WAM E84158) on two slides; 1 (HW 0.73), same data as holotype (WAM E84159) in alcohol.
Other material examined in detail but not included in type series

Australia: Western Australia: 1 (HW not recorded), Mining Area C, c. $95 \mathrm{~km}$ of SE. Wittenoom, Deposit F GF0268R (2256’15.80"S, 11852’21.50"E), 5 February 2008, trap at $51 \mathrm{~m}$, G.B. Pearson, M.D. Scanlon (WAM E84137) on two microscope slides (head separated from body when received); 1 (HW 0.73), Mining Area C, c. $90 \mathrm{~km} \mathrm{WNW.} \mathrm{of} \mathrm{Newman,} \mathrm{Deposit} \mathrm{A} \mathrm{GA0272R}$ (2256’15.80"S, $\left.118^{\circ} 52^{\prime} 21.50^{\prime \prime E}\right), 7$ December 2007, scraping $21 \mathrm{~m}$, J.S. Cocking, M.D. Scanlon (WAM E84138) in alcohol; 1 (HW 0.65), Mining Area C, c. $92 \mathrm{~km}$ WNW. of Newman, Deposit C GC0108R (2255'37.40"S, $\left.118^{\circ} 58^{\prime} 28.00^{\prime \prime E}\right), 13$ January 2008, scraping $24 \mathrm{~m}$, J.S. Cocking, M.D. Scanlon (WAM E84139) in alcohol; 1 (HW 0.70), Mining Area C, c. 94 km WNW. of Newman; Deposit D GD0041R (2255'47.50"S, 118 $57^{\circ} 03.80$ "E), 11 January 2008, scraping 90 m, J.S. Cocking, M.D. Scanlon (WAM E84140) in alcohol; 1 (HW 0.63), Mining Area C, c. $98 \mathrm{~km} \mathrm{SSE.} \mathrm{Wittenoom,} \mathrm{South} \mathrm{Flank} \mathrm{SF0564R}$ (22 59’42.60"S, 118 50’21.20"E), 18 March 2010, scraping 57 m, J.S. Cocking, D.C. Main (WAM E84141) on two slides (slightly dirty and desiccated); 1 (HW 0.60), Mining Area C, c. 98 km SSE. Wittenoom, South Flank SF0565R (2259`40.60"S, 118 50’20.50"E), 18 March 2010, scraping $70 \mathrm{~m}$, J.S. Cocking, D.C. Main (WAM E84142) in alcohol (in poor condition); 1 juv. (HW 0.60), same drill hole as previous, 15 June 2010, scraping, M.K. Curran, G.B. Pearson (WAM E84143) in alcohol (in poor condition); 1 (HW 0.65), Mining Area C, c. $91 \mathrm{~km}$ WNW. of Newman; South Flank SF0752R (2300'03.80"S, 118 56'29.80"E), 24 March 2010, scraping $80 \mathrm{~m}$ - ants present, M.K. Curran, G.B. Pearson (WAM E84144) in alcohol; 1 (HW 0.60), Mining Area C, c. 96 km WNW. of Newman, Packsaddle P3 PSC0899R (2254'03.80"S, 118 56'57.70"E), 26 June 2010, scraping - ants present, M.K. Curran, G.B. Pearson (WAM E84145) in alcohol; 1 (HW 0.65), Mining Area C, c. $95 \mathrm{~km}$ WNW. of Newman, Packsaddle P3 PSC0874R (2254’01.90"S, 118 57’35.10"E), 7 April 2010, scraping $59 \mathrm{~m}$ - ants present, M.K. Curran, J.S. Cocking (WAM E84146) on two microscope slides; 1 (HW 0.50), same data as previous (WAM E84147) in alcohol; 1 juv. (HW 0.50), same data as previous (WAM E84148) in alcohol; 1 juv. (HW not recorded), same data as previous (WAM E84149) in alcohol; 1 (HW 0.70), Mining Area C, c. $86 \mathrm{~km} \mathrm{WNW.} \mathrm{of} \mathrm{Newman,} \mathrm{South}$ Flank East SF0149R (2300’38.70"S, 11859’39.50"E), 26 May 2010, scraping $40 \mathrm{~m}$, J.S. Cocking, D.C. Main (WAM E84150) in alcohol; 1 juv. (HW 0.48), same data as previous (WAM E84151) in alcohol; 1 juv. (HW 0.50), Mining Area C, c. $86 \mathrm{~km}$ WNW. of Newman, Deposit R GR0083R (22 $\left.58^{\prime} 19.00^{\prime \prime S}, 19^{\circ} 01^{\prime} 14.10^{\prime \prime E}\right), 21$ February 2010, stygofauna net $74 \mathrm{~m}$ - ants present, G.B. Pearson, D.C. Main (WAM E84152) in alcohol; 1 (HW 0.50), same data as previous (WAM E84153) on two slides; 1 (HW 0.63), Mining Area C, c. $93 \mathrm{~km} \mathrm{NW}$. of Newman, Packsaddle P4 PSD0115R (2254'07.10"S, 118 59'19.20"E), 27 June 2010, scraping - ants present, M.K. Curran, G.B. Pearson (WAM E84154) in alcohol; 1 (HW 0.63), Mining Area C, c. $93 \mathrm{~km} \mathrm{NW}$. of Newman, Packsaddle P4 PSD0147R (2254’05.40"S, 11859’22.70"E), 27 June 2010, scraping, M.K. Curran, G.B. Pearson (WAM E84155) in 
alcohol; 1 (HW 0.80), Mining Area C, c. $95 \mathrm{~km} \mathrm{SE}$. of Wittenoom, GBRS0180 (2255’32.52"S, 11852’34.64"E), 7 November 2013, scraping 12 m, S.R. Bennett, J.W. Quartermaine (WAM E84136) on two slides; 1 (HW 0.70), Mining Area C, c. $95 \mathrm{~km} \mathrm{SE}$. of Wittenoom, GF0268R (2256’15.80"S, 118 52’21.50"E), 6 December 2007, scraping 51 m, J.S. Cocking, M.D. Scanlon (WAM E84135) on two slides.

\section{DIAGNOSIS}

This species is distinguished from Dodecastyla bifida by its much longer antennae (20-21 articles vs 13-14) and by the simple lateral macrochaetae of its urotergites (vs abiesiform macrochaetae in D. bifida if the illustrations in Silvestri (1905) are correct).

\section{DESCRIPTION}

\section{Male}

Body length: up to about $4.4 \mathrm{~mm}$ (WAM E84136); thorax length: $1.5 \mathrm{~mm}$ (or $0.35-0.38 \mathrm{H}+\mathrm{B}$ ); thorax width: $1.33 \mathrm{~mm}$, widest at meso or metathorax; antennae about 0.6 times $\mathrm{H}+\mathrm{B}$, cerci about 0.2 times $\mathrm{H}+\mathrm{B}$ extending beyond the apex of urotergite $\mathrm{X}$ by a little less than the length of urotergite $\mathrm{X}$, median dorsal appendage broken in all specimens but almost complete in specimen E84157 being about twice the length of the cerci. Body ateluroid (Figure 3). Scales in alcohol preserved specimens without colour and ovoid, rays on dorsal scales (Figure 4) not or only just protruding beyond the margin of the scale, those on the scales of the ventral surface protruding slightly (Figure 5). Macrochaetae mostly simple or slightly apically bifurcate, tergites with a submarginal row of abiesiform macrochaetae (Figure 6), posterior setae of head modified to flattened, longitudinally striated and apically forked, appearing somewhat similar to the dorsal abiesiform setae of the body but tapering along their length (Figure 7).

Head as in Figure 8, wider than long, without scales but with numerous setae, some simple and others apically bifurcate, those nearer to the posterior margin flattened, tapering scale-like setae. Antennae (Figure 9) long with 20 to 21 articles (in WAM E84158), pedicel about half as long as the scape, with fovea consisting of a small circular field of short pointed setulae on the inner ventral face, article three with 10 trichobothria (Figures 10 and 11), although with an often indistinct separation between articles three and four it can appear that there are 12 trichobothria; article four short, articles five to eight becoming longer, articles subdivided from article eight or nine, last article with feathered papilla typical of the Atelurinae (Figure 12), articles four to 14 or 16 with two trichobothria, remaining articles with only one trichobothria, when articles subdivided the trichobothria are only present on the distal subarticle. Mandibles strong with row of macrochaetae along the outer face (Figure 13), and well developed incisor and molar regions (Figure 14). Maxilla (Figures 15 and 16), lacinia with single strong tooth, several lamellate processes that merge into a pectinate process that is slightly shorter than the tooth, seven setae on inner margin proximal to lamellate processes, galea about same length as lacinia with single prominent apical papilla; apical article of maxillary palp (Figure 17) 2.1-2.4 times longer than wide and 1.4-1.5 times longer than penultimate article, with three apical papillae, second and third article with some stronger setae subapically. Labium (Figure 18) longer than wide; labial palp somewhat elongated, apical article ovoid shape (Figure 19), about 1.2-1.6 times longer than wide with usual $3+2+1$ apical papillae.

Thoracic nota (Figures 20-23) with posterior border straight to slightly concave, lateral margins with small simple setae and a larger macrochaeta in the posterior corner on each side, posterior border with row of subequidistant abiesiform setae set back from margin with ends just surpassing the posterior margin of the nota, several small setulae on disc in lateral quarter of each nota and some placed between the marginal setae. About 17-18 abiesiform macrochaetae on pronotum, about 14-16 on mesonotum and 11-14 on metanotum. In contrast to those of the abdomen, the single preserved abiesiform seta of the nota is only about as long as the adjacent scale on the nota.

Legs very long (Figures 24-26), tibia L/W ratio of legs PI 3.8-4.3, PII 3.3-4.3, PIII 3.3-5.7; tarsi L/W ratio PI 8.8-9.0, PII 8.3-12.2, PIII 9.0-12.7. Some scales on all coxae. Transverse row of about three apically bifurcated and one simple macrochaeta across the small sclerite at the base of the coxa of PI. Coxa with some longer thin and four to five longer stronger setae along the outer margin and several stronger setae on the end of the inner margin over the articulation; trochanter short with fine setae; femur with two long macrochaetae on the posterior bulge and another longer seta between these and the trochanter, a single longer lyriform spine subdistally on the outer margin; tibia with four strong macrochaetae on ventral face and posterior margin as well as three strong lyriform spines subapically on the outer margin and a long ventral apical spur; tarsi with four articles, basal article as long as following three articles together, with oblique join to next article, pretarsus with three claws, the medial claw being slightly shorter and straighter; lamellate pulvilli absent.

Urotergites become progressively narrower posteriorly; paratergites fold strongly under body with distinct carina at the side of the body; suture between tergite and paratergite often indistinct but tergite easily tears along this line when preparing slide preparations. Much of urotergite I hidden under the metanotum (Figure 3). Urotergites I-IX (Figures 27-29), with submarginal row of sub-evenly spaced abiesiform setae that are about 1.5 times the length of adjacent scales along the posterior margin, decreasing in number posteriorly from 12 on urotergite I to eight on urotergites V and VI, six on urotergites VII and VIII and only two or four (WAM E84157) on urotergite IX. Lateral corners with one longer delicately apically bifurcate seta and then two shorter simple setae at the level of the suture with the paratergites, as well as two simple or delicately apically bifurcate setae on the outer margin (Figure 27). There may be occasional setulae at about the level of the row of abiesiform setae as well as associated with the urotergal chaetotaxy. Urotergite IX (Figure 29) with postero-lateral corner produced backwards with one strong macrochaeta and several smaller seta on each lateral margin. Urotergite $\mathrm{X}$ similar in shape for both sexes (Figure 30), posterior corners acute but not strongly elongated, each bearing an apical macrochaeta. Males with small fields of sensory cones present on the underside on 


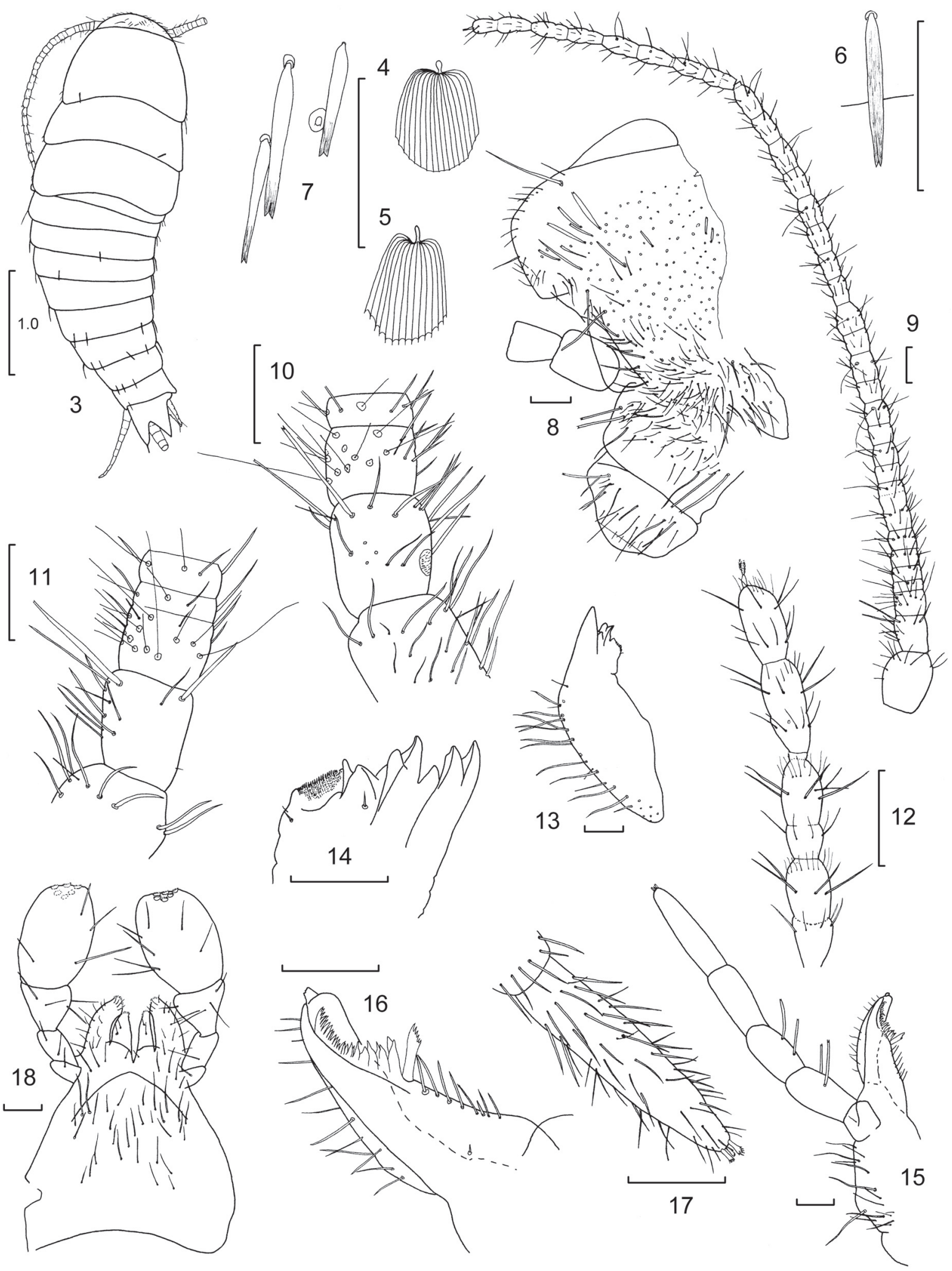

FIGURES 3-18 Dodecastyla crypta sp. nov., holotype male (WAM E84156) unless otherwise indicated by specimen number: 3, habitus; 4, dorsal abdominal scale; 5, ventral abdominal scale; 6, abiesiform macrochaeta of urotergite VIII; 7, head setae (WAM E84158); 8, head, right side (WAM E84158); 9, antenna (WAM E84158); 10, antenna, enlargement of four basal articles; 11, idem, (WAM E84158); 12, antenna, enlargement of apical articles (WAM E84158); 13, mandible; 14, idem, enlargement of incisor and molar regions; 15, maxilla (smaller setae omitted from palp); 16, idem, enlargement of apices of lacinia and galea; 17, idem, enlargement of ultimate article of palp; 18, labium (smaller setae omitted from palp). All scale bars $=0.1 \mathrm{~mm}$. 

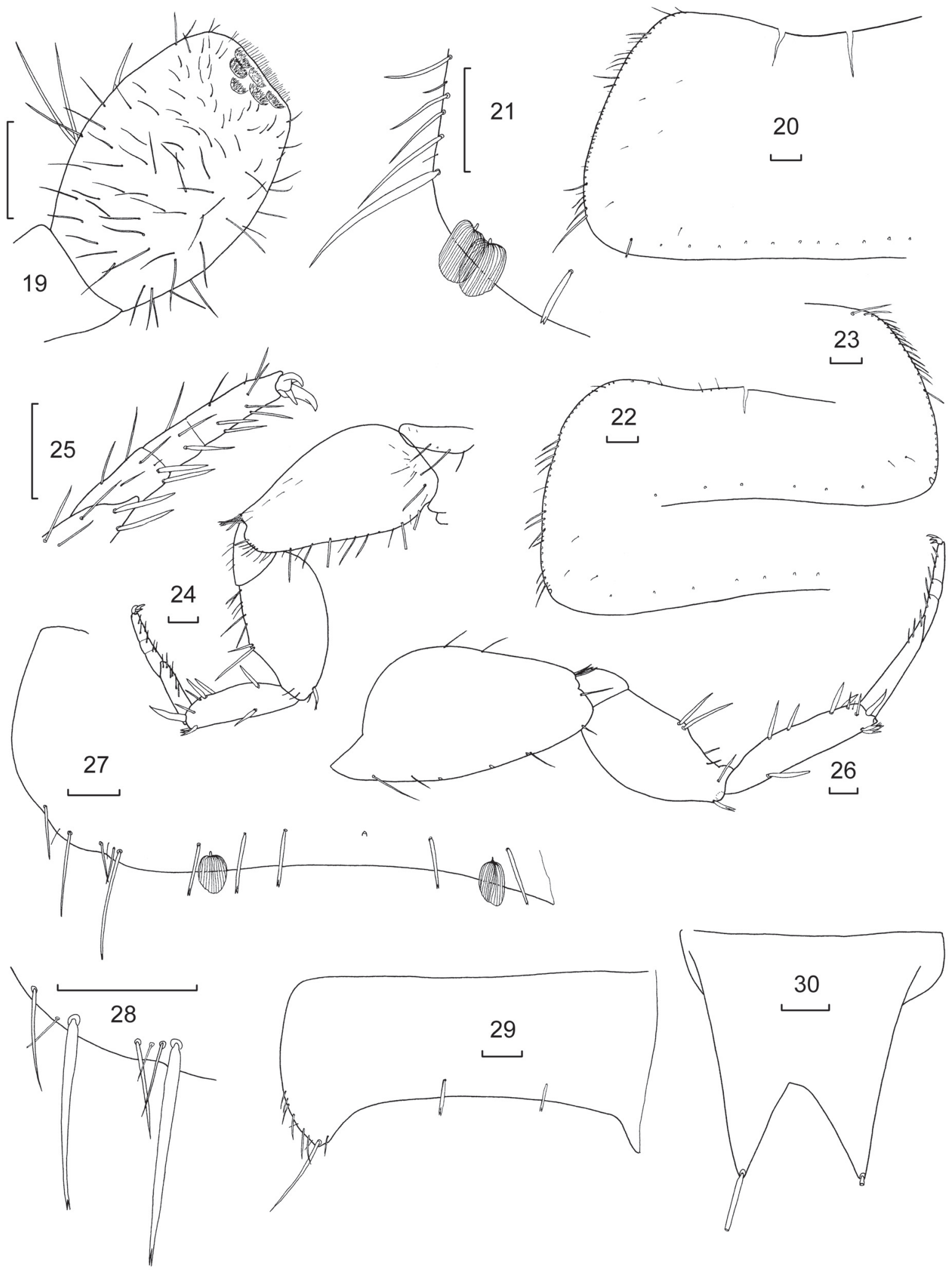

FIGURES 19-30 Dodecastyla crypta sp. nov., holotype male (WAM E84156) unless otherwise indicated by specimen number: 19, last article of labial palp; 20, pronotum, left side; 21, idem, detail of posterolateral corner; 22 , mesonotum, left side; 23, metanotum, right side; 24; prothoracic leg (smaller setae not shown); 25, idem, last three articles of tarsus; 26 metathoracic leg (smaller setae not shown); 27, urotergite IV, left side; 28, idem, detail of left posterolateral corner; 29, urotergite IX (right paratergite missing); 30, urotergite X (female) (WAM E84158). All scale bars $=0.1 \mathrm{~mm}$. 

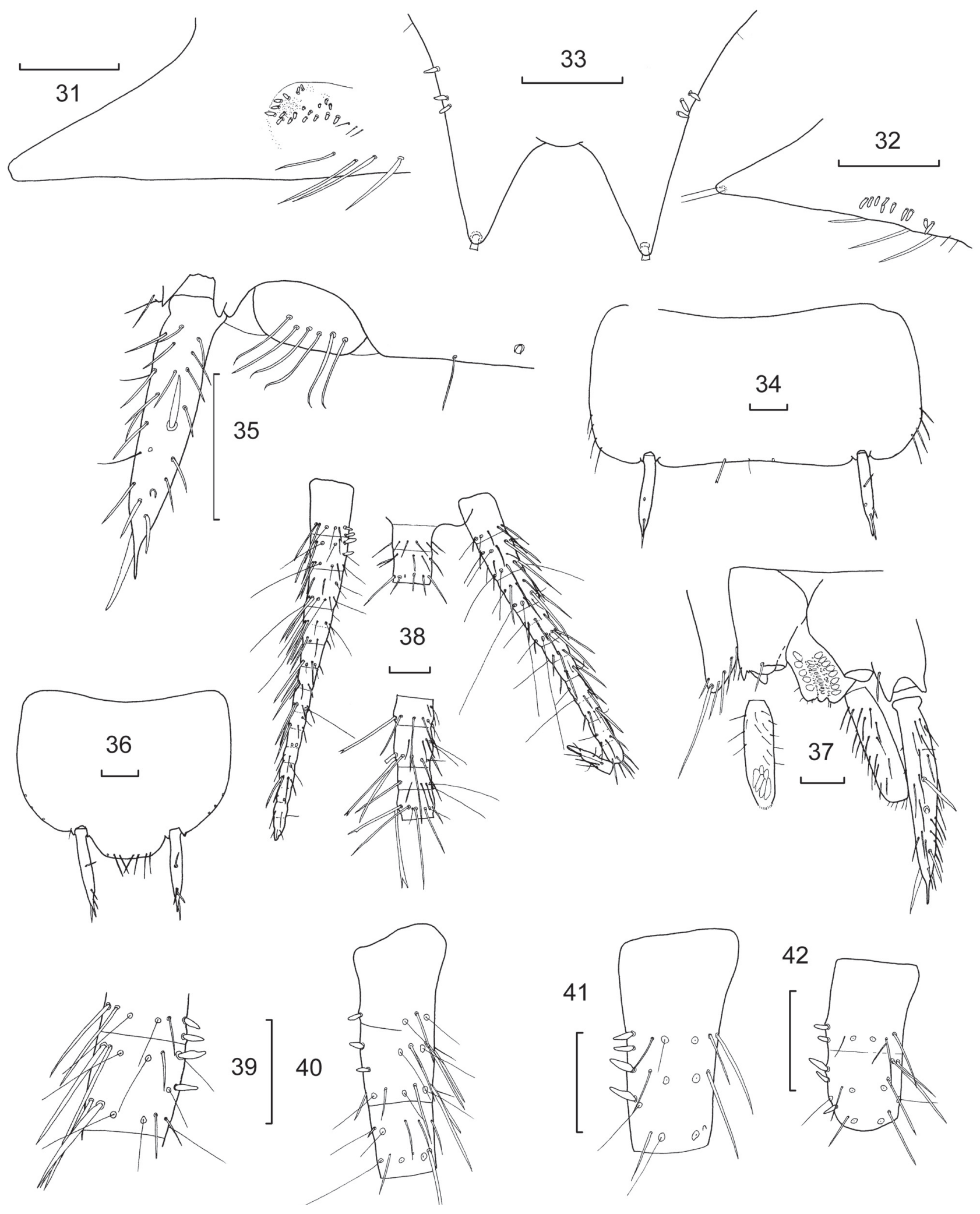

FIGURES 31-42 Dodecastyla crypta sp. nov., holotype male (WAM E84156) unless otherwise indicated by specimen number: 31, underside of urotergite X, left half; 32, idem (WAM E84153); 33, underside of urotergite X (WAM E84137); 34, urosternite V; 35, urosternite VI, detail of right eversible vesicle and stylet; 36, urosternite VIII; 37, urosternite IX, left stylet, parameres and penis as well as right paratergite; 38, cerci and part of median dorsal appendage; 39, basal two articles of right cercus; 40, basal three articles of left cercus (WAM E84137); 41, basal two articles of left cercus (WAM E84136); 42, basal two articles of left cercus (WAM E84153). All scale bars $=0.1 \mathrm{~mm}$. 

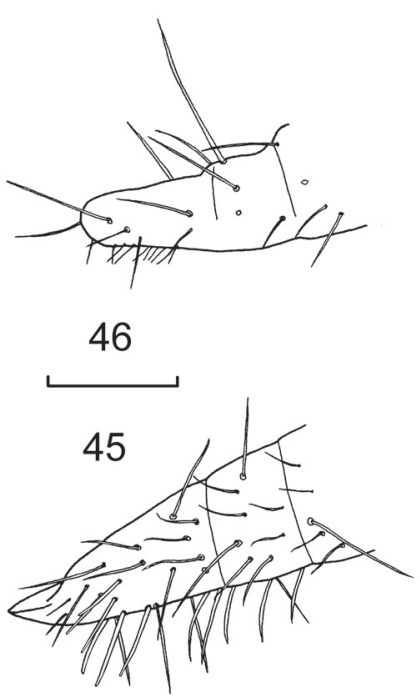

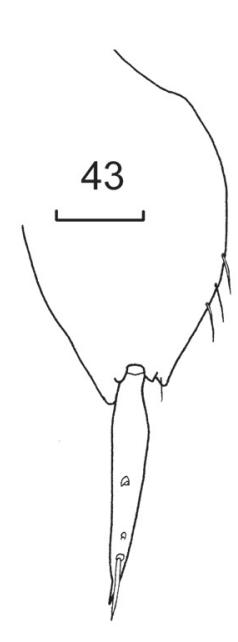

FIGURES 43-46 Dodecastyla crypta sp. nov. paratype female (WAM E84158): 43, right urosternite VIII; 44, genital region showing ovipositor, subgenital plate, stylet IX and outlines of urosternites VIII and IX as well as portion of right paratergite; 45, ovipositor, detail of apex of anterior gonapophysis; 46, idem, detail of apex of posterior gonapophysis. All scale bars $=0.1 \mathrm{~mm}$.

each side adjacent to similar but larger modified setae on the cerci (Figures 31-33). The arrangement of these cones was surprisingly inconsistent, with the cones surrounding a small open, grainy area on the holotype (Figure 31), forming a narrow row in WAM E84153 (Figure 32) and reduced to just three cones on each side in WAM E84137 (Figure 33). The degree of flattening of urotergite $\mathrm{X}$ when mounted and the amount of accumulated dust can make interpretation of the arrangement difficult but does not explain the wide variation observed.

Urosternite I glabrous (lost in slide of holotype), urosternites II-VII (Figure 34) with 1+1 submedial apically bifurcate submarginal setae and often a few small marginal setulae and 3-4 small setae on the postero-lateral corners. Urosternite VI also with $1+1$ eversible vesicles (Figure 35) each armed with six or seven simple setae in a single but slightly irregular row. Urosternite VII with pseudovesicles. Urosternite VIII of male (Figure 36) strongly convex between the stylets with seven submarginal setae. Six pairs of stylets (on urosternites IV-IX), those on IX almost twice as large as those on the anterior segments, stylets with distinct apical spine and some stronger setae subapically and along the stylet as well as smaller setae (Figures 35 and 37). Urosternite IX in male (Figure 37) divided into separate coxites, each bearing a long paramere about 3.5-3.9 times longer than wide (when measured as a slide preparation) each side with a seta laterad to the base. Paramere with glandular region in apical third of dorsal surface. Penis with longitudinal opening with glandular regions on each side.

Lateral cerci about twice the length of urotergite X, consisting of eight articles with the last five articles divided into subarticles with setae as well as some very long trichobothria (Figure 38). Median filament broken in the holotype but the remaining six basal articles without sensory cones, with setae and short trichobothria as well as some very strong, apically forked macrochaetae ventrally. Cerci of mature males with sensory cones on the inner ventral surface of the first two or perhaps three articles. This arrangement can vary from individual to individual but also from side to side on the same specimen (Figures 39-42). Generally with two subequal cones on the basal segment (occasionally just one), followed by a larger and one smaller cone on the second article and in one case with a third cone on the second article (Figure 42). One specimen also had a slightly modified spine on the third article (Figure 40). Remaining articles without cones (cones only visible on right lateral cercus in drawing of terminal filaments of holotype as they are obscured under the edge of the left cercus due to its orientation).

\section{Female}

As for male except pedicel of antennae lacking fovea, urosternite VIII (Figure 43) and IX (Figure 44) divided into separate coxites. Underside of urotergite $\mathrm{X}$ lacking the fields of cones and cerci without basal cones. Subgenital plate (Figure 44) shorter than wide at its base and ovipositor not very thick, of about 11 articles, just surpassing apex of stylets IX. Apical articles of ovipositor (Figures 45 and 46) with anterior gonapophyses having acute triangular apex and about six slightly stronger setae with slightly rounded tips as well as fine tapering setae and usual subapical field of hooks.

\section{ETYMOLOGY}

The species is named crypta from the Latin word for underground passage, referring to it living within small cavities deep underground. 


\section{Dodecastyla rima sp. nov.}

Figures 47-82

http://www.zoobank.org/urn:Isid:zoobank. org:act:ABE1C706-457E-4065-858F-151455076140

\section{MATERIAL EXAMINED}

\section{Holotype}

Australia: Western Australia: (HW 0.63), Cape Preston, c. $69 \mathrm{~km} \mathrm{NNW}$. of Pannawonica, drill hole NB1 (2102’05.70"S, 116 09’25.50"E), 26 September 2007, scraping 18 m, J.S. Cocking, M.D. Scanlon (WAM E84087) on two slides.

\section{Paratypes}

Australia: Western Australia: 1 (HW 0.60), same data as holotype (WAM E84088) in alcohol; 1

(HW 0.55), same drill hole as holotype, 23 April to 18 June 2008, trap, J.S. Cocking, C. Rumens-Thomber (WAM E84089) in alcohol (somewhat desiccated); 1 (HW 0.68), same data as previous (WAM E84090) in alcohol (somewhat desiccated); 1 (HW 0.60), same data as previous (WAM E84091) in alcohol (somewhat desiccated); 1 juv. (HW 0.50), same data as previous (WAM E84092) in alcohol (somewhat desiccated); 1 juv. (HW 0.48), as previous (WAM E84093) in alcohol (somewhat desiccated); 1 (HW 0.65), same data as previous (WAM E84094) in alcohol (somewhat desiccated and in two pieces); 1 (HW 0.68), Cape

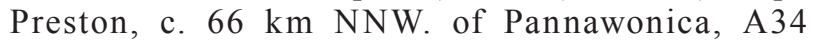
(2104'16.70"S, $\left.116^{\circ} 08^{\prime} 28.30 " \mathrm{E}\right), 11$ February 2008, scraping $25 \mathrm{~m}$, J.S. Cocking, M.D. Scanlon (WAM E84082) on two slides (somewhat desiccated); 1 juv. (HW 0.43), same data as previous (WAM E84083) in alcohol (quite dirty); 1 juv. (HW 0.60), same drill hole as previous, 1 August 2007, stygofauna net 33 m, J.M. McRae, M.D. Scanlon (WAM E84079) in alcohol; 1 juv.

(HW 0.45), same data as previous (WAM E84080) in alcohol; 1 (HW 0.70), same drill hole as previous, 12 February 2008, scraping 25 m, J.S. Cocking, M.D. Scanlon (WAM E84081) on two slides; 1 (HW 0.65), Cape Preston, c. $65 \mathrm{~km}$ NNW. of Pannawonica, A1 $\left(21^{\circ} 04^{\prime} 38.10^{\prime \prime S}, 116^{\circ} 08^{\prime} 35.40^{\prime \prime E}\right), 11$ February 2008, scraping, J.S. Cocking, M.D. Scanlon (WAM E84076) in alcohol; 1 (HW 0.58), Cape Preston, c. $64 \mathrm{~km}$ NNW. of Pannawonica, PH25 (2105'11.50"S, $\left.116^{\circ} 08^{\prime} 25.80^{\prime \prime E}\right), 12$ February 2008, scraping $24 \mathrm{~m}$, J.S. Cocking, M.D. Scanlon (WAM E84095) on two slides; 1 (HW 0.60), Cape Preston, c. 65 km NNW. of Pannawonica, A8 (22 04’30.70"S, $\left.116^{\circ} 08^{\prime} 36.30^{\prime \prime E}\right)$, 27 September 2007, scraping 25 m, J.S. Cocking, M.D. Scanlon (WAM E84084) on two slides; 1 (HW 0.60), same data as previous (WAM E84085) in alcohol (quite dirty); 1 (HW 0.58), same data as previous (WAM E84086) in alcohol (quite dirty and curled over); 1 (HW 0.73), Cape Preston, c. $64 \mathrm{~km} \mathrm{NNW.} \mathrm{of}$ Pannawonica, Z8, (22 05'27.60"S, 116 08'14.20"E), 11 March 2009, scraping 30 m, J.S. Cocking, H.J. Barron (WAM E84133) in alcohol (quite dirty posteriorly and distended); 1 (HW 0.70), same drill hole as previous, 12 February 2008, scraping 24 m, J.S. Cocking, M.D.
Scanlon (WAM E84096) in alcohol (affected by fungus?); 1 (HW 0.73), same data as previous (WAM E84132) in alcohol (affected by fungus?); 1 (HW 0.55), Cape Preston, c. $65 \mathrm{~km}$ NNW. of Pannawonica,

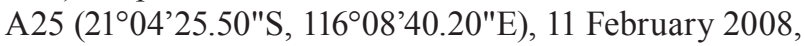
scraping $30 \mathrm{~m}$, J.S. Cocking, M.D. Scanlon (WAM E84077) in alcohol; 1 juv. (HW 0.45), same data as previous (WAM E84078) in alcohol.

\section{DIAGNOSIS}

This species is also distinguished from Dodecastyla bifida by its much longer antennae ( $>19$ articles vs 13-14) and by the simple lateral macrochaetae of its urotergites (vs abiesiform macrochaetae in D. bifida). It can be distinguished from $D$. crypta sp. nov. by the presence of a mound of spinulae (glandular?) mediad to the cones on the underside of urotergite $\mathrm{X}$, by the larger number of abiesiform macrochaetae on the nota (18-22 vs 11-18), the shorter scape relative to the pedicel, the longer cerci, the shorter maxillary palp, the more robust prothoracic legs and the smaller number of setae on the posterior margin of urosternite VIII of the male.

\section{DESCRIPTION}

\section{Male}

Body length: up to about $4.2 \mathrm{~mm}$ in (WAM E84095), up to $4.8 \mathrm{~mm}$ in (WAM E84096) but many specimens showing distended abdomens; thorax length up to $1.65 \mathrm{~mm}$ (or about $0.31-0.44 \mathrm{H}+\mathrm{B}$ ); thorax width: $1.20 \mathrm{~mm}$, widest at meso or metathorax; antennae incomplete in most specimens, up to $3.4 \mathrm{~mm}$ or about 0.7 times $\mathrm{H}+\mathrm{B}$, cerci up to $0.7 \mathrm{~mm}$ (about $0.2 \mathrm{H}+\mathrm{B}$ ) extending beyond the apex of urotergite $\mathrm{X}$ by more than the length of urotergite $\mathrm{X}$, median dorsal appendage up to $1.6 \mathrm{~mm}(0.21 \mathrm{H}+\mathrm{B})$. Body ateluroid (Figure 47). Scales in alcohol preserved specimens without colour, ovoid, rays on dorsal scales (Figure 48) not or only just protruding beyond the margin of the scale, those on the scales of the ventral surface protruding slightly (Figure 49). Macrochaetae mostly simple or delicately apically bifurcate. All tergites with a submarginal row of abiesiform macrochaetae. Posterior setae of head modified to flattened, longitudinally striated and bluntly forked apically (Figure 50).

Head as in Figures 51 and 52, wider than long, without scales but with numerous setae, some simple others apically bifurcate, those nearer to the posterior margin flattened almost abiesiform scale-like setae. Antennae (Figure 53) long with at least 19 articles (in WAM E84081), pedicel about two thirds as long as scape, with fovea consisting of a small circular field of several short pointed setulae on the inner ventral face, article three with 10 trichobothria (Figure 54). Flagellum incomplete in all dissected specimens, article four short, articles five to eight becoming longer, articles subdivided from article eight or nine, articles four to fifteen with two trichobothria, remaining articles with only one trichobothria. When articles are subdivided the trichobothria are only present on the distal subarticle. Mandibles strong with row of macrochaetae along the outer face (Figure 55), and well developed incisor and 


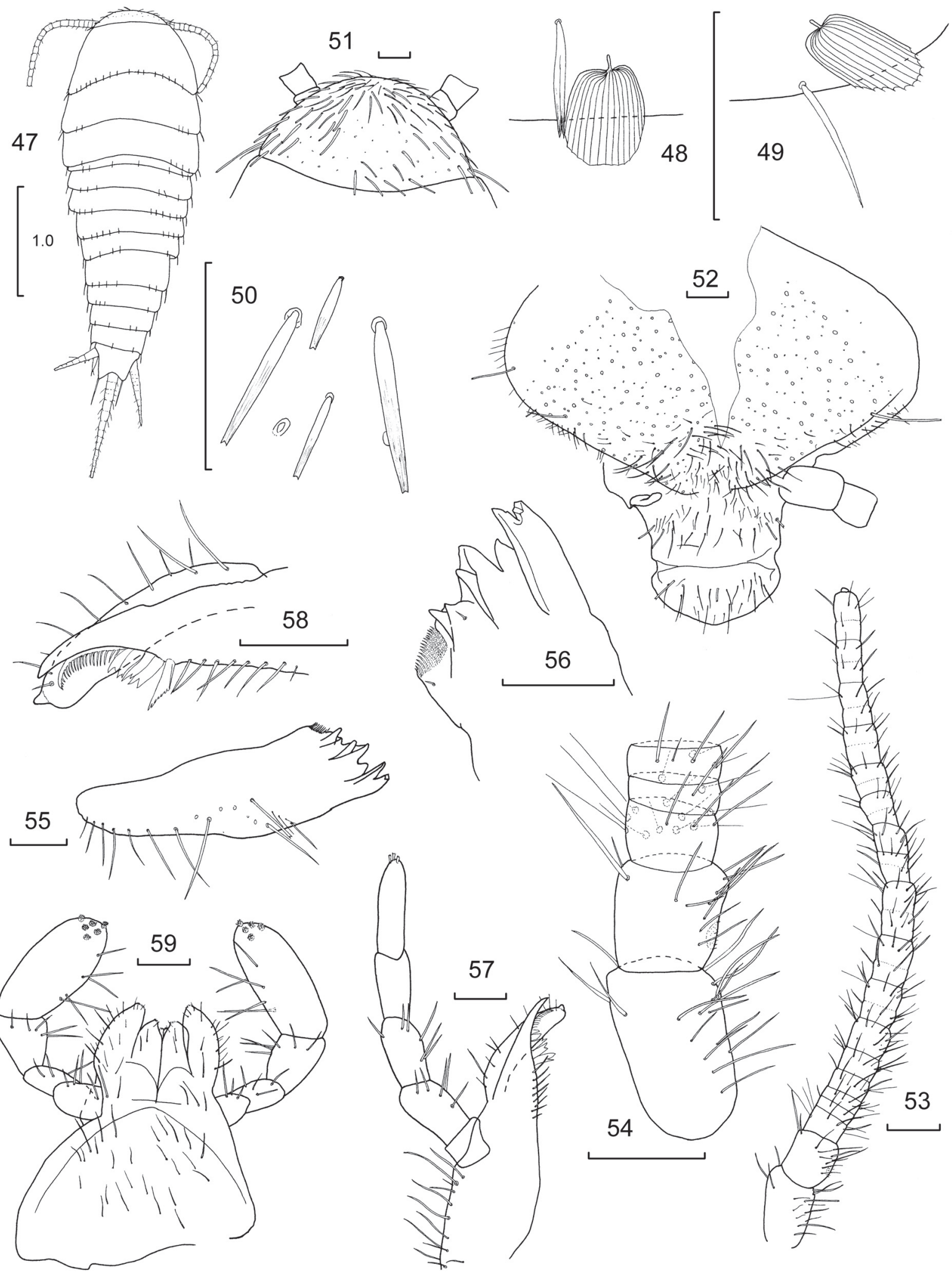

FIGURES 47-59 Dodecastyla rima sp. nov., holotype male (WAM E84087) unless otherwise indicated by specimen number: 47, habitus, composite drawing of holotype with terminal filaments of WAM E84081, note that the thorax is somewhat unnaturally curled giving the false impression that the head is largely hidden by the prothorax (compare with Figure 51); 48, dorsal scale; 49, ventral abdominal scale; 50, setae on head (WAM E84084); 51, head, in normal position (in alcohol) (WAM E84088); 52, head; 53, antenna, incomplete; 54, idem, enlargement of five basal articles; 55, mandible; 56, idem, enlargement of incisor and molar regions; 57, maxilla (smaller setae omitted from palp); 58, idem, enlargement of apices of lacinia and galea; 59, labium (smaller setae omitted from palp). All scale bars $=0.1 \mathrm{~mm}$. 
molar regions (Figure 56). Maxilla (Figures 57 and 58), lacinia with single strong tooth, five lamellate processes that merge into a pectinate process that is about the same length as the tooth, eight setae on inner margin proximal to lamellate processes. Galea equal to or slightly longer than the lacinia with single prominent apical papilla. Maxillary palp fairly short, only about twice the length of the lacinia (from the base of the palp). Apical article of maxillary palp 1.3-2.5 times longer than wide and 1.5-2.1 times longer than penultimate article, with three apical papillae. Second and third articles with some stronger setae subapically. Labium (Figure 59) longer than wide; labial palp not elongated, apical article ovoid (Figure 60 - although the last article is not oriented flat in the illustrations and appears narrower than it actually is), about 1.3-1.6 times longer than wide with some long quite strong setae and the usual $3+2+1$ apical papillae.

Thoracic nota (Figures 61-64) with posterior border straight on pronotum, becoming slightly concave on the meso and meta nota. Lateral margins with small simple setae and a larger macrochaeta in the posterior corner on each side as well as a few small setulae at intervals; the larger macrochaeta in the postero-lateral corners can be quite variable in size, from large as in Figure 62, to not much different to the adjacent setae. Posterior border with row of subequidistant abiesiform setae set back from margin with ends just surpassing the posterior margin of the nota; several small setulae on disc in lateral quarter of each nota and some placed anterior to and between the marginal setae. About 19-22 abiesiform macrochaetae on pronotum, about 18-20 on the mesonotum and 18-21 on metanotum. Abiesiform seta of the nota only about as long as the adjacent scales.

Legs quite long (Figures 65-67), tibia L/W ratio of legs PI 2.7-3.9, PII 3.3-4.0, PIII 4.0-5.0; tarsi L/W ratio PI 5.9-7.8, PII 7.0-9.6, PIII 10.2-12.4. Some scales on coxae of PII and PIII. Transverse row of about two apically bifurcated and two simple macrochaetae across the small sclerite at the base of the coxa of PI. Coxa with some thin and several longer stronger setae along the outer margin and several stronger setae on the end of the inner margin over the articulation. Trochanter short with fine setae. Femur with a long and a strong macrochaeta on the posterior bulge and another longer macrochaeta between these and the trochanter and a single longer lyriform spine subdistally on the outer margin. Tibia with four strong macrochaetae on posterior margin as well as three strong lyriform spines subapically, a strong macrochaeta on the outer margin and a long ventral apical spur. Tarsi with four articles, basal article almost as long as the following three articles together, with oblique join to next article. Pretarsus with three claws, the medial claw being slightly shorter, straighter and thinner; lamellate pulvilli absent.

Urotergites become progressively narrower posteriorly. Paratergites fold strongly under body with distinct carina at the side of the body; suture between tergite and paratergite often indistinct but easily torn during dissection. Much of urotergite I hidden under the metanotum. Posterior margin of urotergites I-IX (Figures 68-70) with submarginal row of sub-evenly spaced abiesiform setae that are only slightly longer than the adjacent scales (most laterad abiesiform seta may be slightly longer than the others). Abiesiform setae decrease in number posteriorly from around 16 on urotergite I to nine on urotergites V and VI, six on urotergite VIII and only four on urotergite IX. Lateral corners with chaetotaxy similar to D. crypta (i.e. one longer delicately apically bifurcate and then two shorter simple setae at the level of the suture with the paratergites, as well as two or three simple or delicately apically bifurcate setae on the outer margin (Figure 69). There may be occasional setulae at about the level of the row of abiesiform setae, notably at each end of row as well as associated with the lateral chaetotaxy. Urotergite IX (Figure 70) with postero-lateral corner only slightly produced backwards with one strong macrochaeta and one small adjacent seta mediad to the macrochaeta and three or four setae along each lateral margin. Urotergite $\mathrm{X}$ similar in shape for both sexes, posterior corners acute but not strongly elongated, each bearing an apical macrochaeta. Underside of urotergite $\mathrm{X}$ of male on each side, with a raised bump provided with numerous tiny spinulae (glandular?) mediad to small fields of sensory cones, adjacent to similar cones on the cerci (Figure 71).

Urosternite I (lost in slide of holotype) with $1+1$ small submedial setae and a single small seta on the posterior corner. Urosternites II-VII (Figure 72) with $1+1$ submedial apically bifurcate submarginal setae and two to three small setae on the postero-lateral corners, without small setulae on posterior margin mediad to the stylets. Urosternite VI also with $1+1$ eversible vesicles (Figure 73) each armed with four to five simple setae in a single row. Urosternite VII with pseudovesicles. Urosternite VIII of male (Figure 74) produced between the stylets with two stronger and two weaker submarginal setae. Six pairs of stylets present (on urosternites IV-IX), those on IX about twice as long as those on the anterior segments. Stylets with distinct apical spine sometimes (but not always) with small subapical 'thorn' (Figure 75), as well as some stronger setae subapically and along their length, in addition to smaller setae. Urosternite IX in male (Figure 76) divided into separate coxites, each bearing a long paramere about 3.7-4.2 times longer than wide (when measured as a slide preparation) with a seta on the coxite laterad to its base. Paramere with glandular region in apical third of dorsal surface and several simple setae. Penis with longitudinal opening with glandular regions on each side.

Lateral cerci more than twice the length of urotergite $\mathrm{X}$, consisting of eight or nine articles with the last four articles divided into subarticles with setae as well as some very long trichobothria (Figure 77); the division between the two basal articles often very difficult to see. The median filament (broken in holotype) of eleven or twelve articles subdividing from about the fourth and further subdivided from about the sixth, with setae and long trichobothria as well as some very strong, apically forked macrochaetae ventrally. Cerci of mature males with sensory cones on the inner and or ventral surface of first two articles. The arrangement can be somewhat variable (compare Figures 78 and 79). Basal article with 


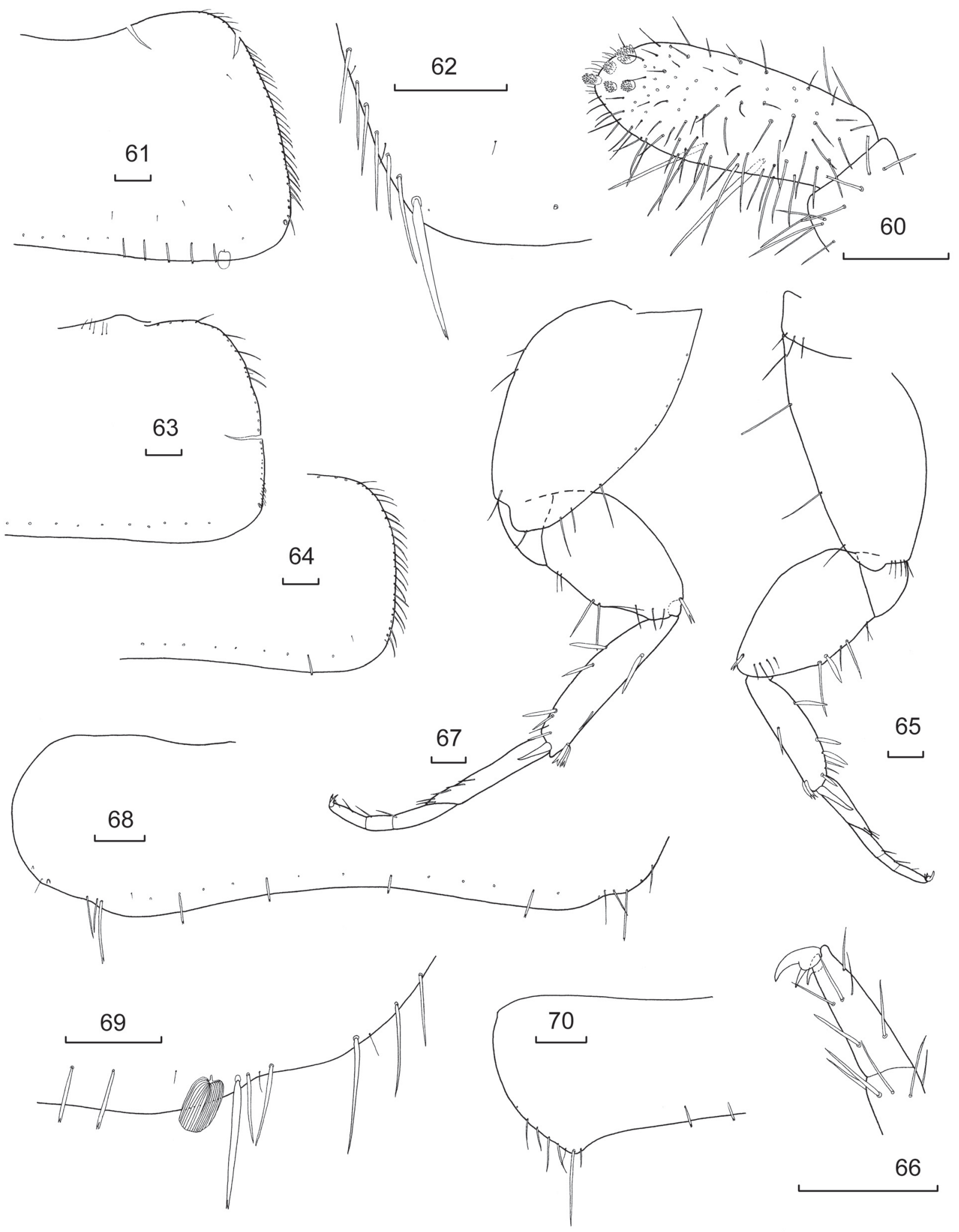

FIGURES 60-70 Dodecastyla rima sp. nov., holotype male (WAM E84087) unless otherwise indicated by specimen number: 60, last article of labial palp; 61, pronotum, right side; 62, idem, detail of left postero-lateral corner; 63, mesonotum, right side; 64, metanotum, right side; 65; prothoracic leg, smaller setae not shown (WAM E84095); 66, idem, pretarsus and last article of tarsus (WAM E84095); 67 metathoracic leg, smaller setae not shown (WAM E84095); 68, urotergite III (?); 69, urotergite VIII, detail of left posterior corner; 70, urotergite IX, left side (WAM E84081). All scale bars $=0.1 \mathrm{~mm}$. 


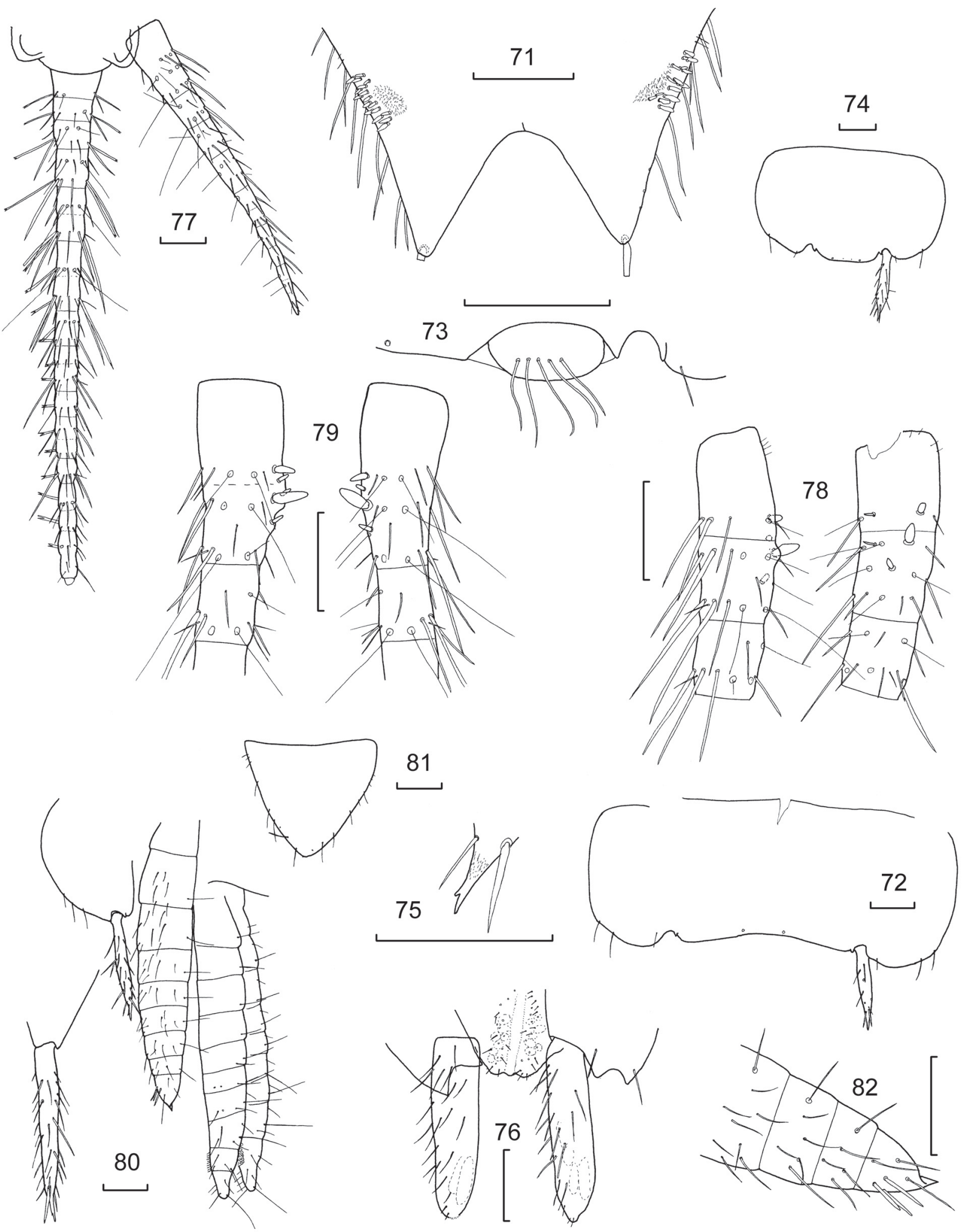

FIGURES 71-82 Dodecastyla rima sp. nov., holotype male (WAM E84087) unless otherwise indicated by specimen number: 71, urotergite $X ; 72$, urosternite IV or V; 73, detail of left eversible vesicle VI (WAM E84081); 74, urosternite VIII of male; 75, apex of stylet IX (WAM E84081); 76, parameres and penis as well as part of coxites IX; 77, cerci and median dorsal appendage of female (WAM E84081); 78, basal three articles of cerci of male; 79, ibid, of another male (WAM E84095); 80, genital region of female with urosternites VIII and IX and their stylets (WAM E84081); 81, subgenital plate (WAM E84081); 82, detail of apex of anterior gonapophysis (WAM E84081). All scale bars $=0.1 \mathrm{~mm}$. 
one medium and sometimes a smaller cone, which may be located more ventrally rather than in line with the other cones. Second article with one larger cone as well as one or two smaller cones, the division between these two articles often difficult to see, remaining articles without cones.

\section{Female}

As for male except pedicel of antennae lacking fovea, urosternite VIII and IX (Figure 80) divided into separate coxites, underside of urotergite $\mathrm{X}$ lacking the fields of cones and field of setulae, cerci without basal cones, subgenital plate (Figure 81) shorter than wide at its base. Ovipositor (Figures 80) not very thick, of about 10 articles, apex of anterior gonapophyses (Figure 82) with acute triangular apex and three slightly stronger setae with more rounded tips as well as fine tapering setae; posterior gonapophyses with rounded tips and usual subapical field of hooks.

\section{ETYMOLOGY}

The species is named rima from the Latin word for crack or crevice, referring, as for the previous species, to it living within small cavities deep underground.

\section{Troglotheus gen. nov.}

\section{http://www.zoobank.org/urn:Isid:zoobank. org:act:60D167B5-9AF1-4AB5-8FDF-F8E48A4B76EB}

\section{TYPE SPECIES}

Troglotheus bifurcus sp. nov.

\section{DIAGNOSIS}

The genus differs from others in the tribe Atopatelurini by the number of stylets (six pairs), the absence of dorsal setae or macrochaetae on the nota (only some small setulae) and the head with only simple or apically bifid setae.

\section{DESCRIPTION}

Medium sized, elongate ateluroid shape, thorax not strongly wider than abdomen, devoid of pigment. Scales multi-radiate with ribs on dorsal scales only slightly surpassing the margins, while those on the ventral surface protrude a little further beyond the posterior margin. Head with mostly simple or apically bifid setae. Antennae with more distal articles subdivided, pedicel of male with obscure fovea.

Mouthparts typical for the Atopatelurini. Mandibles with well developed molar and incisor regions. Maxilla with single-toothed lacinia, a pectinate prostheca that is about the same length as the lacinia, galea about the same length as the lacinia and equipped with a single prominent apical papilla. Maxillary palp with usual three apical feathered papillae. Labium typical for the Atopatelurini.

Lateral margins of thoracic nota with small setae and a single larger macrochaeta in each postero-lateral corner; posterior margin of all nota without setae or macrochaetae, only with some small setulae. Legs typical for Atopatelurini, with a single subapical lyriform spine on each femur and three on each tibia; pretarsi with two lateral claws and a medial empodial claw; pulvilli absent.

Abdomen with paratergites folding strongly around and slightly under the body with distinct carina at the outermost point on the more anterior segments. Posterior margins of urotergites I-IX glabrous, with only a single macrochaeta and some smaller setae present on each of the postero-lateral corners. Urotergite IX with small postero-lateral lobes. Urotergite $\mathrm{X}$ very long and deeply incised on the posterior margin, with a single macrochaeta at the apex on each side; underside of urotergite $\mathrm{X}$ in males with field of cones on each side near the base of the cerci.

Urosternite I glabrous, urosternites II-VII (VIII in ) with $1+1$ submedial setae. Stylets present on segments IV-IX. Eversible vesicles on VI, each armed with several simple setae, pseudovesicles on VII. Posterior margin of urosternite VIII in male protruding between the stylets. Urosternite IX of male divided into separate coxites, each bearing a long paramere. Penis with longitudinal opening.

Cerci of male with cones on the medial ventral surface of the basal two articles; median filament without cones or modified chaetotaxy.

Female lacking fovea on antennae, also lacking cones on underside of urotergite IX and base of cerci. Subgenital plate subtriangular. Ovipositor short and thick.

\section{ETYMOLOGY}

The name of the genus derived from the Greek word troglo for cave to highlight the subterranean habitat of the type species, combined with the suffix -theus, commonly used with Atelurinae.

\section{DISCUSSION}

The genus clearly fits within the Atopatelurini but is unusual in lacking dorsal setae or macrochaetae. It has all the other key characters such as the exposed head covered with setae (without scales), the typical unmodified body scales, the male pedicel with a fovea but lacking an apophysis, a non-elongated prostheca and a single conule on the galea, lyriform spines on the legs, urosternite VI with exsertile vesicles bearing a row of setae, pseudovesicles on urosternite VII, the typical female genitalia with subgenital plate and large spindleshaped ovipositor bearing only fine setae and the base of the cerci and the underside of urotergite $\mathrm{X}$ in mature males with cones and the median dorsal appendage without modified chaetotaxy.

Apart from the absence of dorsal chaetotaxy and the very elongate urotergite $\mathrm{X}$, it is close to other genera in the tribe, especially Dodecastyla with which it also shares the same number of stylets. Dodecastyla in turn is quite close to Pseudogastrotheus and another, as yet undescribed genus, which have stylets on urosternites VI-IX and V-IX respectively. The number of stylet pairs within the Zygentoma is however not necessarily a strong character to determine higher groups as it seems to be fairly unstable. While it is practical at the moment to sort the species into genera based on the number of pairs of stylets, this may eventually be shown to be of secondary significance. 


\section{Troglotheus bifurcus sp. nov.}

Figures 83-119

\section{http://www.zoobank.org/urn:Isid:zoobank. org:act:623678E0-12DA-4E7E-BF04-6B6961C64CD6}

\section{MATERIAL EXAMINED}

\section{Holotype}

Australia: Western Australia: (HW 0.70), Valley of the Queens, c. $60 \mathrm{~km} \mathrm{~N}$. of Tom Price, drill hole SM1573 (22 $\left.2^{\circ} 7^{\prime} 13.5^{\prime \prime} \mathrm{S}, 117^{\circ} 44^{\prime} 54.6^{\prime \prime} \mathrm{E}\right), 13$ March 2013, scraping from hole $8 \mathrm{~m}$ deep, J.S. Cocking and S.R. Bennett (WAM E84068) on two slides.

\section{Paratypes}

Australia: Western Australia: 1 (HW 0.68), same data as holotype (WAM E84069) in two pieces- head thorax and abdominal segments I-VII in alcohol and abdominal segments IX \& X (missing ovipositor) on one slide; 1? (HW 0.65), same data as holotype (WAM E84070) in alcohol (incomplete specimen, head, thorax and abdominal segments I-VII); 1 (HW ?), Valley of the Queens, c. $60 \mathrm{~km} \mathrm{~N}$. of Tom Price, SM5423 (22 $\left.2^{\circ} 06^{\prime} 42.6^{\prime \prime} \mathrm{S}, 117^{\circ} 45^{\prime} 39.8^{\prime \prime} \mathrm{E}\right), 13$ March 2013, scraping 25 m, J.S. Cocking and S.R. Bennett (WAM E84071) in alcohol (posterior half only); 1 (HW 0.83), Valley of the Queens, c. $60 \mathrm{~km} \mathrm{~N}$. of Tom Price, SM1934 (22 $07^{\circ} 11.9^{\prime \prime S}$, $117^{\circ} 44^{\prime} 54.6^{\prime \prime E}$ ), 13 September 2012, scraping $11 \mathrm{~m}$, J.S. Cocking and S.R. Bennett (WAM E84072) in two pieces, each part mounted on separate microscope slide (i.e. head, thorax and abdominal segments I-IV on one slide, V-IX on another); 1? (HW 0.83), same data as previous (WAM E84073) incomplete specimen, head, thorax and abdominal segments I-III on one slide; 1 (HW 0.83), Valley of the Queens, c. $60 \mathrm{~km} \mathrm{~N}$. of Tom Price, SM1934 (22 $\left.2^{\circ} 7^{\prime} 13.0^{\prime \prime} \mathrm{S}, 17^{\circ} 45^{\prime} 36.4^{\prime \prime} \mathrm{E}\right), 3$ September 2011, scraping $10 \mathrm{~m}$, J.S. Cocking and S.R. Bennett (WAM E84074) on two slides (incomplete, head, thorax and abdominal segments I, VII-X); 1 (HW 0.80), same data as previous (WAM E84075) in two pieces with each piece mounted on a separate slide (i.e. head, thorax and abdominal segment I on one slide, abdominal segments $\mathrm{V}(\mathrm{VI})-\mathrm{X}$ on the other).

\section{DESCRIPTION}

\section{Male}

Body length: up to about $7.4 \mathrm{~mm}$ (WAM E84072); thorax length: $2.1 \mathrm{~mm}$ (or about 0.25 times $\mathrm{H}+\mathrm{B}$ ); thorax width: $1.35 \mathrm{~mm}$, widest at meso or metathorax; cerci damaged in all specimens except for one partial specimen (WAM E84069) where the cerci extend a little beyond the apex of urotergite X. Median dorsal appendage broken in all specimens but almost complete in specimen (WAM E84069) being about twice the length of the cerci and extending well beyond the posterior limit of urotergite $\mathrm{X}$. Body form elongate tapering (Figure 83), quite narrow at posterior of abdomen $(0.63 \mathrm{~mm})$, devoid of pigment. Scales in alcohol preserved specimens without colour and ovoid, their rays only just surpassing their free border, slightly more so with the ventral scales (Figures 84-85).
Macrochaetae mostly simple or some apically bifurcate, those near the posterior corners of the head thicker than the rest, although most of the posterior macrochaetae are lost in the specimens available.

Head (Figure 86) not much wider than long, without scales and with numerous curved macrochaetae some quite robust. Antennae (Figure 87) incomplete in all specimens, (only the basal 17 articles preserved in holotype; 20+ articles in WAM E84074). Pedicel (Figure 88) about half as long as the scape, with obscure fovea consisting of a small circular field of short pointed setulae on the inner ventral face, article three with eight (?) trichobothria, although an indistinct joint with article four can sometimes give the impression that there are ten trichobothria; article four short, articles five to seven becoming longer, articles subdivided from article eight or nine, article 20 obscurely further subdivided into a total of four subarticles (Figure 89), articles four to fourteen (or sixteen in WAM E84074) with two trichobothria, remaining articles with only one trichobothria, when articles subdivided the trichobothria are present only on the distal subarticle. Mandibles strong with row of macrochaetae along the outer face (Figure 90), and well developed incisor and molar regions (Figure 91). Maxilla (Figure 92), lacinia with single strong tooth, several lamellate processes that merge into a pectinate process that is about the length of the tooth or slightly shorter, five single and two pairs of small setae on inner margin proximal to lamellate processes. Palp of medium length about two and a half times the length of the lacinia (from the base of the palp), apical article of maxillary palp 4.3-5.3 times longer than wide and 1.5-2.4 times longer than penultimate article. Ultimate article with three apical papillae; second and third articles with some stronger setae subapically. Labium (Figure 94) longer than wide; labial palp somewhat elongated, apical article long ovoid shape (Figure 95), about 1.5-1.6 times longer than wide with usual $3+2+1$ subapical papillae.

Thoracic nota (Figures 96-98) with posterior border slightly concave. Lateral margins with small simple setae and a single macrochaeta in the posterior corner on each side, posterior border glabrous, several small setulae on disc and along margins.

Legs very long (Figures 99-103), tibia L/W ratio of legs PI 3.8-4.1, PII 4.3-5.6, PIII 4.1-5.2; tarsi L/W ratio PI 6.8-8.7, PII 8.3-11.5, PIII 13.8-14.6. Legs with numerous short and long setae and some scales on the coxae only of PII and PIII. Transverse line of about three apically bifurcated and one simple macrochaetae across the small sclerite at the base of the coxa of PI. Coxae with some longer thin setae along the outer margin and one on face and several stronger setae on the end of the inner margin over the articulation. Trochanter short. Femur with two long macrochaetae on the posterior bulge and a single longer lyriform spine subdistally on the outer margin. Tibia with three strong macrochaetae on ventral face and posterior margin as in Figures 99-101, as well as three strong lyriform spines subapically on the outer margin and a long ventral apical spur (Figure 102). Tarsi with four articles, basal article elongate (on PII and PIII longer than 


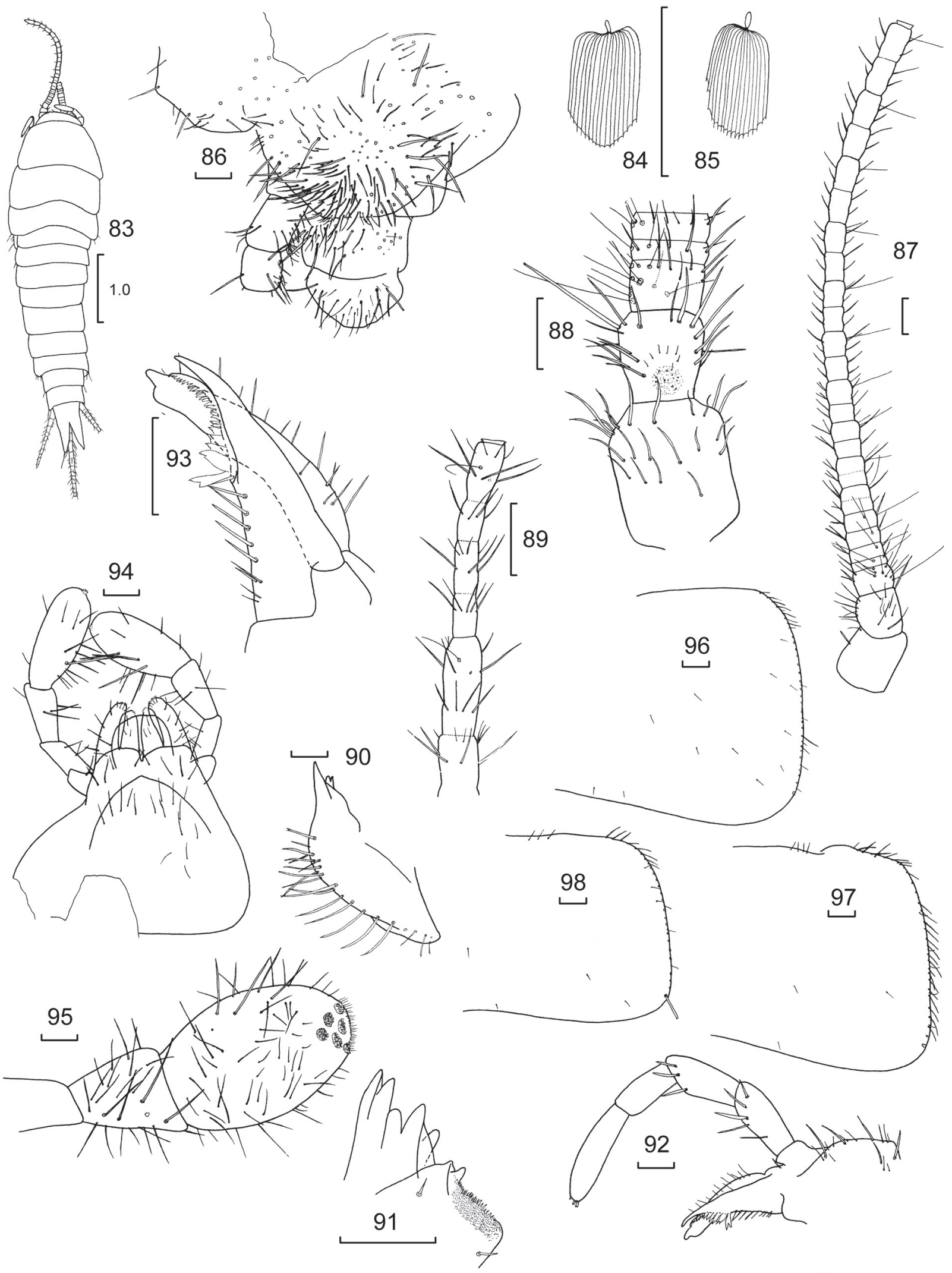

FIGURES 83-98 Troglotheus bifurcus sp. nov., holotype male (WAM E84068) unless otherwise indicated by specimen number: 83, habitus, composite of holotype and terminalia of WAM E84069; 84, dorsal scale; 85, ventral scale; 86, head (damaged posteriorly during dissection); 87, antenna, incomplete; 88, idem, enlargement of five basal articles; 89, idem, enlargement of most apical surviving articles (WAM E84074); 90, mandible; 91, idem, enlargement of incisor and molar regions; 92, maxilla (smaller setae omitted from palp); 93, idem, enlargement of apices of lacinia and galea; 94, labium (smaller setae omitted from palp); 95, idem, enlargement of apical article of palp; 96, pronotum, right half; 97, mesonotum, right half; 98, metanotum, right half. All scale bars $=0.1 \mathrm{~mm}$, unless otherwise indicated. 


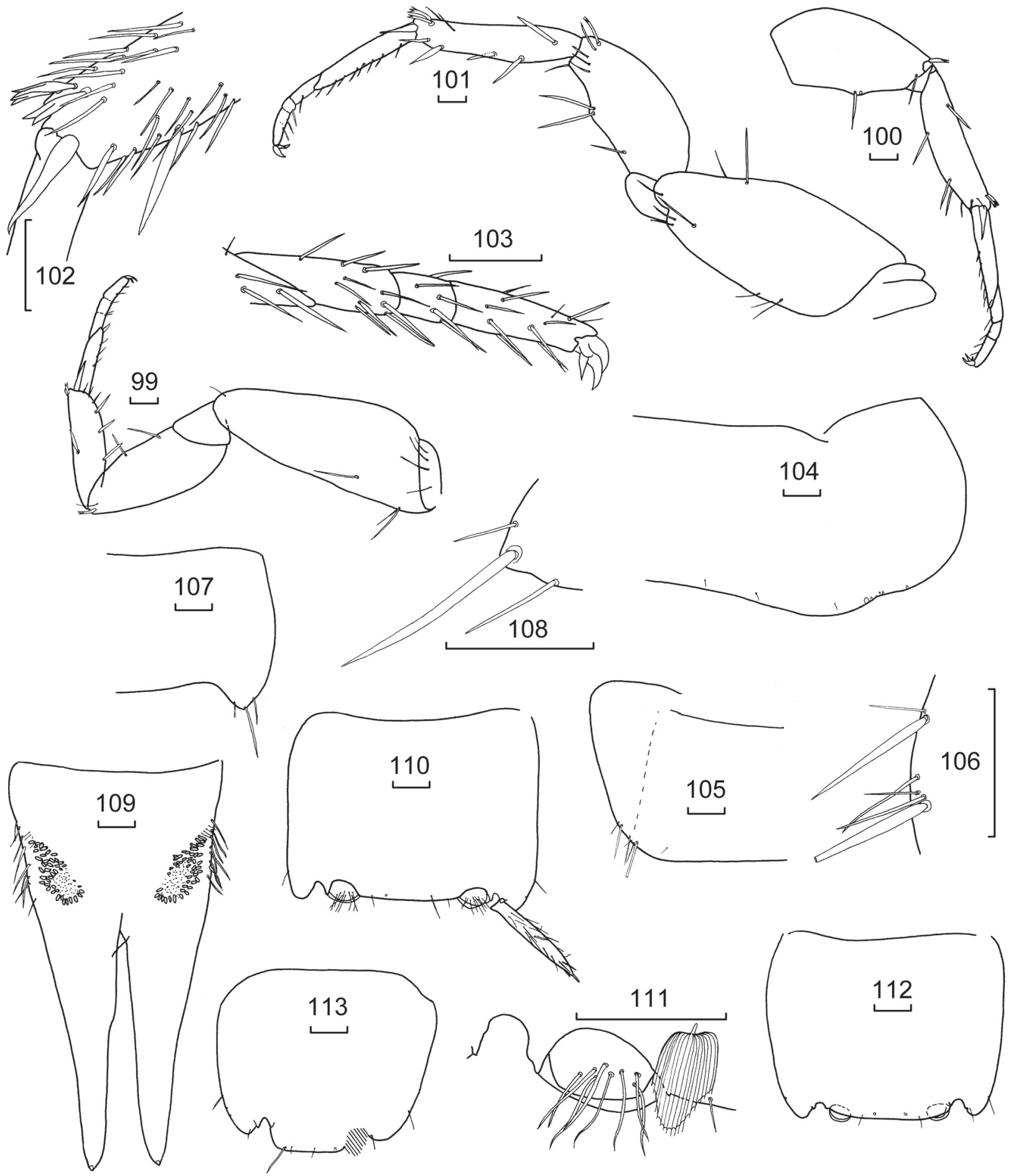

FIGURES 99-113 Troglotheus bifurcus sp. nov., holotype male (WAM E84068) unless otherwise indicated by specimen number: 99, prothoracic leg (smaller setae omitted); 100, mesothoracic leg excluding coxa and trochanter (smaller setae omitted); 101, metathoracic leg (excluding smaller setae); 102, idem, distal end of tibia; 103 , idem, distal three articles of tarsus and pretarsus; 104, urotergite III, right half; 105, urotergite VIII, left half; 106, idem, enlargement of postero-lateral chaetotaxy; 107, urotergite IX, right half; 108, idem, enlargement of postero-lateral chaetotaxy; 109, urotergite X, from below (WAM E84074); 110, urosternite VI; 111, idem, enlargement of right vesicle; 112, urosternite VII; 113, urosternite VIII. All scale bars $=0.1 \mathrm{~mm}$. 
following three articles together) with oblique join to next article. Pretarsus with medial claw being slightly shorter and straighter than the laterals (Figure 103).

Urotergites become progressively much narrower posteriorly; paratergites fold strongly under body with distinct carina at the side of the body. Suture between tergite and paratergite often indistinct but tergite easily tears along this line when preparing slide preparations. Urotergites I-VIII without setae or macrochaetae along posterior margin except for one macrochaeta, two smaller setae and a setula on the margin either side of the suture with the paratergite and another marginal seta and setula a small distance laterad of these (Figures 104-106). There are also four setulae somewhat remote from the posterior margins. Urotergite IX (Figure 107) with postero-lateral corner produced backwards with one macrochaeta and a smaller seta on each side (Figure 108). Urotergite $X$ (Figure 109) with greatly elongated posterior corners in both sexes and each apex with an apical macrochaeta. Underside of urotergite $\mathrm{X}$ in the male with fields of sensory cones surrounding an open area of granular appearance located on each side adjacent to similar but larger cones on the cerci.

Urosternite I glabrous (middle region of sternite damaged in holotype but intact on WAM E84074). Urosternite VI with $1+1$ eversible vesicles (Figures 110 and 111) each armed with eight or nine simple setae in two irregular rows; urosternite VII (Figure 112) with pseudovesicles. Urosternite VIII (Figure 113) of male produced medially with setulae mediad to the submarginal $1+1$ setae. Stylets on IX almost twice as large as those on the segments IV-VIII. Stylets with distinct apical spine and some stronger and also smaller setae. Urosternite IX in male (Figure 114) divided into separate coxites, each bearing a long paramere. Paramera with glands on dorsal surface, about 4-5.8 times longer than wide (when measured as a slide preparation) with a seta laterad to the base and another near the posterior end of the lateral margin. Penis with longitudinal opening with glandular regions on each side.

Terminal filaments mostly incomplete; one female specimen, consisting only of urotergite $\mathrm{X}$ and urosternite

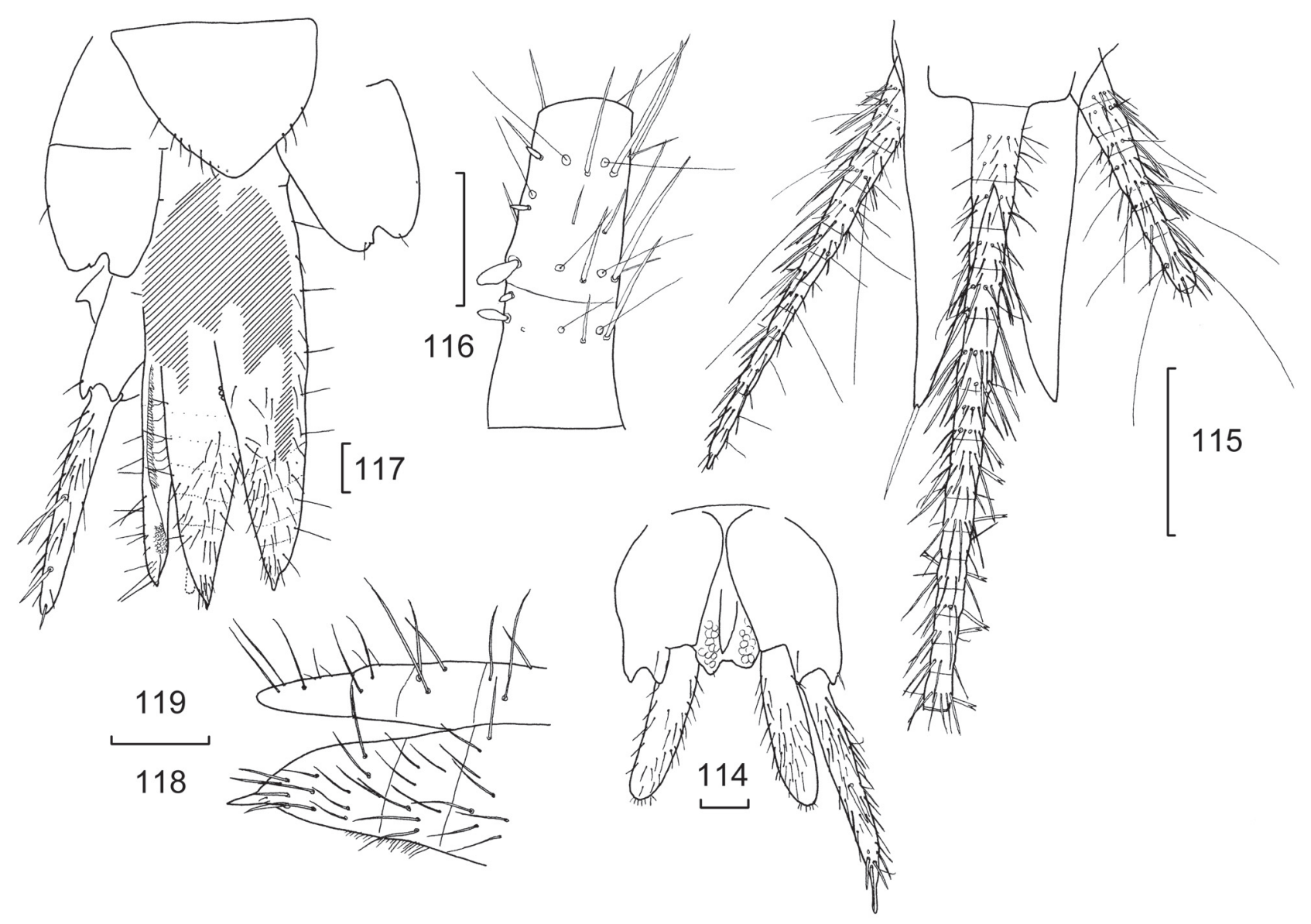

FIGURES 114-119 Troglotheus bifurcus sp. nov., holotype male (WAM E84068) unless otherwise indicated by specimen number: 114, urosternite IX of male with stylet IX and parameres; 115, terminal filaments and outline of urotergite X (WAM E84069); 116, base of cercus (WAM E84074); 117, urosternites VIII and IX of female, with ovipositor and stylet IX (cross-hatched area indicates dark material within specimen obscuring view) (WAM E84075); 118, apex of gonapophyses VIII; 119, apex of gonapophyses IX (WAM E84075).

All scale bars $0.1 \mathrm{~mm}$. 
IX (without ovipositor) had one complete lateral cercus and most of the median cercus (Figure 115). The lateral cerci consists of about ten articles with setae as well as some very long trichobothria, the cercus extending to about the level of the apex of the macrochaeta on the end of urotergite $\mathrm{X}$. The median filament consists of more segments $(>15)$, with setae and short trichobothria as well as some very strong, apically forked macrochaetae ventrally. Cerci of mature males with two sensory cones on the inner ventral surface of the first article, followed by a larger and two smaller cones on the second article (Figure 116), remaining articles apparently without cones (somewhat obscured by dust and urotergite $\mathrm{X}$ in holotype).

\section{Female}

As for male except, pedicel of antennae lacking fovea, urosternite VIII and IX (Figure 117) divided into separate coxites, underside of urotergite $\mathrm{X}$ lacking the fields of cones, cerci without basal cones, subgenital plate (Figure 117) slightly shorter than wide at its base and ovipositor short and thick, of about 10 articles, not quite attaining the end of stylets IX, apical articles as shown in figures 118 and 119.

\section{ETYMOLOGY}

The species is named bifurcus from the Latin word for two-pronged, referring to the greatly elongated and bifurcated urotergite $\mathrm{X}$.

\section{DISCUSSION}

Schäffer's original description of Lepismina bifida, while very good for the time, contained some errors such as the number of abdominal stylets and it did not adequately describe the dorsal chaetotaxy. Silvestri (1898) moved the species and other Atelurinae, to his new genus Grassiella. In 1902 Silvestri redescribed the species based on topotypic material, correcting the number of abdominal stylets to six pairs, suggesting the head was almost bare, describing the dorsal chaetotaxy as a submarginal row of narrow truncate apically bifurcate scales and reporting the pretarsus to consist of two outer curved claws and another acute apically curved claw between them. Escherich (1903) believed Silvestri's Grassiella bifida could not be the same as Lepismina bifida Schäffer because it had a different number of stylets. He renamed Silvestri's 1902 description and material as Grassiella silvestrii. In 1905, after receiving material from both Schäffer and Silvestri, Escherich confirmed the material to be the same thus making $G$. silvestrii a junior synonym of $G$. bifida. At the same time, he transferred all described atelurin species to Atelura v. Heyden, 1855. In 1905, Silvestri redescribed the species as Atelura bifida; this time describing the head as having numerous and quite long setae, especially at the front, but does not mention if they are simple or of flattened appearance. In 1912, Silvestri restored the genus Grassiella with a revised description but made no specific mention of bifida. Wygodzinsky (1958) suggested the species may not belong in Grassiella due to the presence of rows of macrochaetae on the posterior borders of the tergites and the absence of a process on the pedicel of the male. Paclt (1974) examined new material from Chile as well as two syntypes and erected the genus Dodecastyla for the species including mention, for the first time, of skin-like empodial appendages (pulvilli?) at the base of the claws. Unfortunately there is some concern that the more recent material from Coronel examined by Paclt may not be the same species as that described by Schäffer and Silvestri because the male specimen, still in acohol, is much larger (almost $5 \mathrm{~mm}$ vs $3.5 \mathrm{~mm}$ ). Further specimens from Coronel in the Hamburg collection referred to by Paclt (1979) are not atelurins at all but belong to the Microcoryphia. Some of Schäffer's original material is still available in the University of Hamburg entomological collection but is described as being quite dirty and/or in rather poor condition and quite fragile (Koch pers. comm.). Given the existing ambiguities, a redescription of this species would be welcome and could be completed more satisfactorily when additional topotypic material is obtained.

\section{BIOLOGY, HABITAT AND DISTRIBUTION}

The presence of Atelurinae in deep subterranean habitats is somewhat surprising, however the observations of atelurin silverfish in caves mentioned in the Introduction suggests that some species, like the rest of the Nicoletiidae, are not averse to travelling or living far underground. In addition it would appear that their potential hosts may also take advantage of deep subterranean habitats, perhaps only in the search for water in otherwise arid regions.

Troglotheus bifurcus is known from only four drill holes within $1.9 \mathrm{~km}$ of each other at the Valley of the Queens. Three are on the valley floor and the fourth is on the lower slopes of surrounding hills. Between one and six other species of troglofauna were collected together with Troglotheus bifurcus. These were hemipterans, cockroaches, symphylans, pauropods, pseudocorpions, beetles, schizomids and nicoletiin silverfish (Trinemura sp. and Hemitrinemura sp.). Unidentified ants were collected with Troglotheus bifurcus at three of the holes, while termites were collected with Troglotheus bifurcus at two holes and were recorded in a sample from a third hole when Troglotheus bifurcus was not collected (but probably present in the matrix around the hole). Thus, it is possible Troglotheus bifurcus is associated with an ant or termite species.

The likely range of Dodecastyla crypta is unclear at this stage. Animals with similar morphology to that of Dodecastyla crypta are frequently collected during troglofauna sampling from west of the Packsaddle Range along the Hamersley Range to Ophthalmia Range and east of Newman. We have insufficient morphological and genetic information to determine whether these animals represent a single taxon and have selected animals from a single drill hole in 
the Packsaddle Range as the type series. It is likely, however, that Dodecastyla crypta occurs at least throughout the Packsaddle and Jirrpalpur Ranges and we treat all animals in this area as Dodecastyla crypta, giving the species an east-west range of at least $20 \mathrm{~km}$.

Holes yielding Dodecastyla crypta were on ridge lines or hills. Four and five other troglofauna species, respectively, were collected with Dodecastyla crypta at drill hole PSD0149R on 11 April and 27 June 2010. These were unidentified hemipterans, cockroaches, schizomids and centipedes. Unlike Troglotheus bifurcus, the occurrence of Dodecastyla crypta does not appear to be obviously associated with ants or termites. Ants were present in only about a quarter of the holes in the Jirrpalpur and Packsaddle Ranges that yielded what is considered to be Dodecastyla crypta. Termites were present in a single hole.

Most records of Dodecastyla crypta in the Packsaddle and Jirrpalpur Ranges were collected by scraping but five trap samples from depths of 15, 35, 50, 51 and $51 \mathrm{~m}$ yielded specimens. These specimens were much deeper than any ants or termites are likely to occur and provides further evidence that it is unlikely that ants or termites are hosts for Dodecastyla crypta. We suggest that Dodecastyla crypta either lives independently or is associated with another troglofauna species.

In the case of Dodecastyla rima, all material examined was included in the type series. It was collected over a smaller range than Dodecastyla crypta $(6 \mathrm{~km}$ vs $20 \mathrm{~km})$ although a very small creek lies between two of the collection sites (e.g. the holotype was collected from the north eastern side of the small creek and the female paratype from the south-west). While variability was seen in the configuration of cones on the cerci and underside of urotergite $\mathrm{X}$ in the males, all male specimens displayed the raised areas with small points mediad to the combs and all displayed the higher number of abiesiform setae on the tergites compared to those seen in Dodecastyla crypta.

Dodecastyla rima was collected on 18 occasions, with up to four other troglofauna species collected in the same sample. Altogether, six other groups of troglofauna were collected with Dodecastyla rima (pseudoscorpions, schizomids, diplurans, centipedes, beetles and enchytraeid worms). A species of nicoletiin silverfish belonging to the genus Hemitrinemura was collected four times. Dodecastyla rima was collected with unidentified ants on four occasions and once with termites.

Despite the occasional co-occurrence with termites or ants, none of the three atelurin silverfish described here displays strong apomorphies that we would associate with an obligate dependency on a social insect host (usually seen more with termitophiles than myrmecophiles) so any relationships with ants or termites may be more facultative than obligatory. The co-occurrence with troglobitic species, such as schizomids, and the fact at least 15 other (undescribed) species of Atelurinae have been collected from deep in exploration holes (J.M McRae unpublished data) suggests that atelurin silverfish are regular inhabitants of subterranean habitats in the Pilbara.

\section{MORPHOLOGY}

All three subterranean species have quite thin and delicate cuticles and their general body form is less robust than seen in other epigean Atopatelurini species such as Australiatelura tasmanica (Silvestri, 1949). The frequent collection of the species in exploration holes, suggests however, a degree of troglomorphism, although by no means extreme. Troglotheus bifurcus shows the greatest degree of troglomorphism with the body being longer and more slender than other atelurins. None of the three species however shows the greatly elongated appendages of highly adapted troglobites. Nor do they have exceptionally long setae. While this may be related to their occurrence in small spaces across the subterranean landscape, rather than occurrence in the large voids of caves, we believe it best to consider the species as troglophiles rather than obligate subterranean insects because of the lack of strong troglomorphies. They might quite easily be able to survive within the nests of ants or termites, where habitat conditions are also quite stable. However life as an inquiline species can be hazardous and the silverfish would need to retain the ability to move rapidly to escape capture by the hosts. The development of long spindly legs and slower movements typical of troglobites are unlikely to be advantageous under such conditions. It is possible that the adaptations we usually consider as beneficial to an inquiline existence such as the shortening of appendages, the tendency to ovoid shape and the need for speed, are in conflict with those we consider as beneficial for a troglobitic existence.

\section{ZOOGEOGRAPHY}

Assuming D. crypta and D. rima have been correctly placed within Dodecastyla, the presence of this genus in both Chile and Australia suggests an Antarctic/ Gondwana origin for the genus, possibly in line with that known for the Nothofagus forests of both countries. In their analysis of the paleogeography of the region, Cook and Crisp (2005) note that Australia and South America separated from Antarctica between 30 and 50 My ago. If this represents the last common ancestor then the close similarity between the Australian and Chilean species would suggest a quite conservative morphology within this genus. The Australian ancestors of these two Dodecastyla species were probably forest dwelling species that took refuge, perhaps in company with their hosts, deeper within the soil as the climate dried out from the mid-Miocene (c. 10-15 My ago).

Troglotheus on the other hand is much more derived that other Australian Atopatelurini. It is the only species to lack setae on the posterior margins of the tergites. The extremely elongated urotergite $\mathrm{X}$ is also unique, 
although in its basic shape with a deep triangular incision and the presence of cones on the underside in the males, it conforms to the usual pattern. In the arrangement of urosternal vesicles it is like many of the other genera including Dodecastyla, Atopatelura Silvestri, 1908 from Central Africa, Arabiatelura Mendes, 1995 from the Middle East, Australiatelura Mendes, 1995 and Ausallatelura Smith, 2007 both from Australia, the widespread Pseudogastrotheus Mendes 2003 from Africa, South and SE Asia, Australia and Brazil, and Rasthegotus Mendes, 2001 from Africa. Ecnomatelura Wygodzinsky, 1961 from South Africa differs in vesicles VI being located laterad to the stylets. Only Dodecastyla has the same number of stylets. Allatelura hilli Silvestri, 1947 and Galenatelura deflexa Smith, 2009, both endemic to Australia, do not have the characteristic vesicles with setae on urosternite VI and their placement within the Atopatelurini is probably yet to be fully established.

\section{ACKNOWLEDGEMENTS}

The authors would like to thank Prof. Markus Koch of the Zoologisches Institut und Zoologisches Museum, Universität Hamburg, Hamburg, Germany (and now University of Bonn) for information on the types of Lepismina bifida in the Hamburg University collection. We would also like to thank Dr Stuart Halse of Bennelongia Environmental Consultants for his valuable input into the manuscript. The first author is appreciative of the co-operation and financial support from Bennelongia Environmental Consultants for this taxonomic work

\section{REFERENCES}

Buick, R., Thornett, J.R., McNaughton, N.J., Smith, J.B., Barley, M.E. and Savage, M. (1995). Record of emergent continental crust $\sim 3.5$ billion years ago in the Pilbara craton of Australia. Nature 375: 574-577.

Cook, L.G. and Crisp, M.D. (2005). Not so ancient: the extant crown group of Nothofagus represents a post-Gondwanan radiation. Proceedings of the Royal Society B. Biological Sciences 272: 2535-2544.

Escherich, K. (1903). Beiträge zur Kenntnis der Thysanuren. I Reihe. Zoologischer Anzeiger (XXVI) 697: 345-366.

Escherich, K. (1905). Das System der Lepismatiden. Zoologica (Stuttgart) 43: 1-164.

Espinasa, L. and Espinasa Closas, R. (2006). Troglobites from the lava tubes in the Sierra de Chichinautzin, Mexico, challenge the competitive exclusion principle. AMCS Bulletin 19 / SMES Boletín 7: 271-273.

Grassi, B. and Rovelli, G. (1889). Tavola analitica dei Tisanura da noi finora riscontrati. Bollettino della Società Entomologica Italiana 21: 3-8.

Guzik, M.T., Austin, A.D., Cooper, S.J.B., Harvey, M.S., Humphreys, W.F., Bradford, T., Eberhard, S.M., King, R.A., Leys, R., Muirhead, K.A. and Tomlinson, M. (2010). Is the Australian subterranean fauna uniquely diverse? Invertebrate Systematics 24: 407-418.

Halse, S.A. and Pearson, G.B. (2014). Troglofauna in the vadose zone: comparison of scraping and trapping results and sampling adequacy. Journal of Subterranean Biology 13: 17-34.

Luke, G.J., Burke, K.L. and O'Brien, T.M. (2003). Evaporation data for Western Australia. Resource Management Technical Report 65, Department of Agriculture Western Australia, Perth, 32 pp.

Martin, H.A. (2006). Cenozoic climate change and the development of the arid vegetation in Australia. Journal of Arid Environments 66: 503-563.

Macphail, M.K. and Stone, M.S. (2004). Age and palaeoenvironmental constraints on the genesis of the Yandi channel iron deposits, Marillana Formation, Pilbara, northwestern Australia. Australian Journal of Earth Sciences 51: 497-520.

Mendes, L.F. (1986). Novos dados sobre os Zygentoma do Zaire. Notas e descrição de Gastrotheus (G.) ornatus sp. n. (Ateluridae). Revue Zoologique Africaine (Bruxelles) 100: 289-305.

Mendes, L.F. (1994). Thysanura. In Juberthie, C. \& Decu, V. (eds) Encyclopaedia Biospeologica. vol. 1: 285-287. Société de Biospéologie: Moulis (C.N.R.S).

Mendes, L.F. (2012). Description of the male of Lasiotheus Paclt, 1963, its implication in Atelurinae supra-generic taxonomy and keys for the genera (Insecta: Zygentoma). Zootaxa 3573: 18-32.

Paclt, J. (1974). Neue Beiträge zur Kenntnis der ApterygotenSammlung des Zoologischen Staatsinstituts und Zoologischen Museums Hamburg. IV. Epigäische Nicoletiidae (Thysanura). Entomologishe Mitteilungen aus dem Zoologischen Museum Hamburg (4) 89: 543-549.

Paclt, J. (1979). Neue Beiträge zur Kenntnis der ApterygotenSammlung des Zoologischen Instituts und Zoologischen Museums der Universität Hamburg. VI. Weitere Doppel- und Borstenschwänze (Diplura: Campodeidae: Thysanura: Lepismatidae und Nicoletiidae). Entomologishe Mitteilungen aus dem Zoologischen Museum Hamburg 105: 221-228.

Remington, C.L. (1954). The suprageneric classification of the order Thysanura (Insecta). Annals of the Entomological Society of America 47: 277-286.

Schäffer, C. (1897). Apterygoten. Ergebnisse der Hamburger Magalhaensische Sammelreise 2: 1-48.

Silvestri, F. (1898). Primera noticia acerca de los Tisanuros argentinos. Comunicationes del Museo Nacionale de Buenos Aires 1: 33-37.

Silvestri, F. (1902). Materiali per lo studio dei Tisanuri. I-V. Bollettino della Società Entomologica Italiana 33: 204-249.

Silvestri, F. (1905). Thysanura. Zoologische Jahrbucher. Supplement 6 (Fauna Chilensis): 773-806.

Silvestri, F. (1912). Tisanuri finora noti del Messico. Bollettino del Laboratorio di Zoologia Generale e Agraria della Facoltà Agraria in Portici 6: 204-221.

Silvestri, F. (1949). Nuove specie di Lepismatidae (Insecta Thysanura) termitofile e mirmecofile. Bollettino del Laboratorio di Zoologia Generale e Agraria della Facoltà Agraria in Portici 9: 32-39.

Smith, G.B. (1998a). Zygentoma (Thysanura). In: Houston, W.W.K. and Wells, A. (eds), Zoological Catalogue of Australia. Vol. 23: 7-20, 397-399, 403. Archaeognatha, Zygentoma, Blattodea, Isoptera, Mantodea, Dermaptera, Phasmatodea, Embioptera, Zoraptera. CSIRO Publishing: Melbourne, Australia. 464 pp. 
Smith, G.B. (1998b). Review of the Australian Nicoletiinae (Zygentoma : Nicoletiidae). Invertebrate Taxonomy 12: $135-189$.

Smith, G.B. (2006). New species of Metrinura Mendes (Zygentoma: Nicoletiidae) from Queensland, Australia. Australian Journal of Entomology 45: 163-167.

Smith, G.B., Eberhard, S.M., Perina, G. and Finston, T. (2012). New species of short range endemic troglobitic silverfish (Zygentoma: Nicoletiidae) from subterranean habitats in Western Australia's semi-arid Pilbara region. Records of the Western Australian Museum 27: 101-116.

Stach, J. (1935). Die Lepismatiden-Fauna Ägyptens. Annales Musei Zoologici Polonici, Warszawa 11(4): 27-111.
Watson, J.A.L. (1970). Apterygota (primitively wingless insects). In Mackerras, I.M. (ed). Insects of Australia: 217-223. Commonwealth Scientific and Industrial Research Organisation and Melbourne University Press: Melbourne, Victoria.

Wygodzinsky, P. (1958). Sobre algunos "Nicoletiidae" americanos (Thysanure, Insecta). Acta Zoologica Lilloana 16: $97-120$.

Wygodzinsky, P. (1963). On J. Paclt's Nicoletiidae (Thysanura) in the "Genera Insectorum". Annals and Magazine of Natural History (13) 6: 265-269.

MANUSCRIPT RECEIVED 11 JULY 2014; ACCEPTED 19 AUGUST 2014. 